\title{
Assessing Building Habitability after an Earthquake Using Building Typology and Damage Grade. Application in Lorca, Spain
}

\author{
Sandra Martínez-Cuevas: ', M. Carmen Morillo Balsera Belén Benito , Yolanda Torres , \\ Jorge Gaspar-Escribano Alejandra Staller , and Cesar García-Aranda
}

\begin{abstract}
The present study proposes a statistical methodology to rate the habitability of different types of buildings after an earthquake. The first step was to rank variables that affect the vulnerability of a building and formulate a statistical study with a discrimination index that makes it possible to identify buildings as habitable or non-habitable. This ranking applied the criteria established in various international guidelines that are used to distinguish between habitable (undamaged/no structural damage) and non-habitable buildings (structural damage). The proposed methodology was applied to a database with information about buildings and damage grade experienced following the 2011 earthquake in Lorca. The approach presented could be extended to other regions where neccessary data are available.
\end{abstract}

\section{KEYWORDS}

Seismic vulnerability assessment; building typology; building habitability; damage grade; risk assessment; inferential statistics

\section{Introduction}

Because of the resulting human and economic losses, several recent earthquakes have highlighted the importance of planning cities and the significant impact of building behavior on these losses. Classifying buildings by type and assigning vulnerability classes is one of the critical tasks in any seismic risk study. To this end, buildings are grouped into classes of vulnerability, depending on their performance and on the degree of damage to be expected after a seismic movement. This classification is based on the near impossibility of studying each building - with its structural and non-structural characteristics and irregularities - separately in risk studies. Thus, buildings, with their peculiarities, are instead grouped by areas or regions comprised of thousands or millions of buildings. Grouping buildings by typology makes seismic risk studies more efficient while, at the same time, preserving the integrity of expected outcomes. It also helps define a common taxonomy that may change depending on construction practices and building design (Brzev et al. 2012; Lang 2013).

Most methodologies used to rate building vulnerability after a seismic event analyze building performance based on structure and construction, without taking other factors into account. Some recent empirical methodologies have introduced urban design parameters that can make buildings more or less vulnerable to seismic events, depending on the location of the building and other factors that can condition building behavior during an earthquake (irregular plan, vertical irregularity, the difference in height compared to adjoining buildings, etc.). In the present study, design parameters that affect the seismic vulnerability of buildings are referred to as "urban modifiers". Martínez-Cuevas et al. (2017) undertook an exploratory study relating the frequencies of observed damage grades in buildings presenting different urban modifiers, using as case study the 2011 Lorca earthquake. The 
present paper takes a step further in the statistical analysis and propose a discrimination index to assess building habitability

The city of Lorca is located in the Region of Murcia, an earthquake prone area at the southeast of Spain. In May, 2011, a Mw = 5.1 event occurred in a shallow faut that crosses Lorca (e.g., Morales et al. 2014 and references therein), causing nine fatalities, notable damage to buildings, thousands of displaced people and economic losses of about $1000 \mathrm{M} €(\mathrm{CCS}, 2014)$. According to these effects, an EMS intensity of VII was assigned to the earthquake in the city (IGN 2011).

Despite seismic provisions are in force in the the Region of Murcia since the decade of 1960 , severe damage was observed in certain areas. Numerous modern buildings showed soft stories, as well as short and trapped columns, which performance was poor. Indirect damage was also observed, caused by the fall of broken pieces of non-structural elements, such as parapets or balconies. Overall, the 2011 Lorca earthquake was considered too destructive for its relatively small magnitude in a region where the seismic code is applied (Benito et al. 2012).

In this paper, a classification of habitability after an earthquake for different building typologies on different types of soil in the city of Lorca after the 2011 May $11^{\text {th }}$ earthquake is presented. The aim is to look at how different combinations of independent variables (the type of structure, urban modifiers and soil class) correlate with structural and no structural damage (dependent variable) (Fig. 1). In this study, the damage is related to the habitability of the building and the term "no structural damage" means that there is no damage to the structural elements, so after the earthquake the building is considered to be habitable. Assessing the extent of damage would define buildings as habitable or nonhabitable. This would, in turn, make it possible to determine whether or not it was safe to allow the public to access a building after an event and identify which buildings may be considered habitable. The results obtained in the present study are presented as an index and a habitability scale that are then used to create a Table of building typologies on different classes of soil that may be either habitable (accessible) or uninhabitable (inaccessible).

The principal contribution of this study is a procedure to quickly determine the habitability of buildings based on a complete definition of the type of structure, the urban configuration and the soil condition of the building location. In addition, as the spatial analysis is carried out within a Geographical Information System (GIS), the non-habitable areas could be easily identified and mapped making it possible to project new zones where homeless families could be rehoused.

This information could be valuable for Civil Protection to help devising contingency plans, quantifying the number of the people who live in these buildings and planning for their subsequent rehousing needs. This type of carthography could also be used by local and regional governments to identify the areas that should be rebuilt according to the obtained habitability criteria in the General Urban Development Plans. The methodology presented here could be replicated in other regions where data on building damage after an earthquake are available.

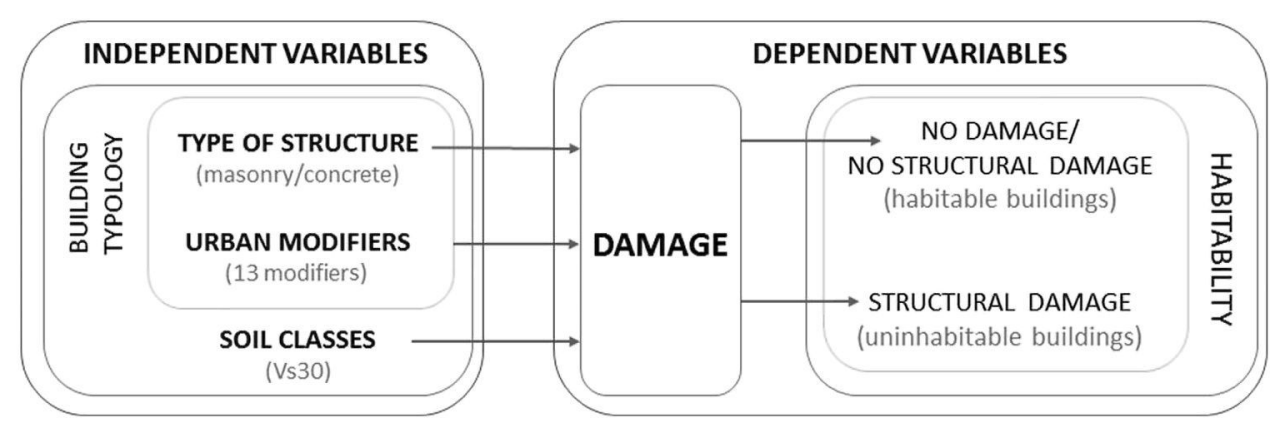

Figure 1. Correlated variables in the present study. 


\section{Background in Vulnerability Assessment}

The main objective of any seismic vulnerability rating for buildings is to identify types of construction that may respond differently to seismic movements and group these types into classes in order to evaluate their response and estimate the extent of losses to be expected. Seismic vulnerability refers to the extent to which a building or set of buildings may be predisposed to experiencing damage after an earthquake. For practical purposes, different typologies that behave similarly during a seismic event are generally grouped in the same class, which is assigned based principally on the structural system (considering earthquake resistant design), assessing the seismic performance of structures (De Risia, Godaa, and Tesfamariam 2019) and the materials used in construction. The first classifications proposed (e.g., MSK-64 [Medvedev, Sponheuer, and Karnik 1965], EMS-98 [Grünthal 1998]) sometimes assigned different types of buildings, made of different materials, the same vulnerability class. Later, HAZUS-99 introduced a new concept, diving the building stock into clusters of prevalent types of buildings called Model Building Typologies (MBT). This new classification considers the structural system, height, and seismic design code as the main factors when assigning a class. Most subsequent studies and scales have followed this guideline when assessing buildings (PAGER [Jaiswal and Wald 2008], RISK-UE [Milutinovic and Trendafiloski 2003], PSI [Spence et al. 1991]).

Building typology depends mainly on local building materials, geology and geography, climatic conditions, and the socioeconomic status of the occupants. Depending on the region or country, specific typologies exhibit a wide range of different characteristics that make identifying regional typologies an arduous task. Any vulnerability class system must group typologies that have a similar structural system and are built of similar construction materials together while assigning the former greater weight in determining vulnerability. Furthermore, such aspects as the height of the building, the standards of seismic-resistant design applied, the year of construction and urban modifiers must also be taken into account.

The number of building typologies identified and vulnerability classes may vary depending on the methodologies and scales applied. Studies have been carried out both on a global scale (WHE (www. world-housing.net), PAGER (Jaiswal and Wald 2008), GEM (Brzev et al. 2012) and CEQID (Spence et al. 2011)) and at the regional level (ATC-13, EMS-98 [Grünthal 1998], RISK-UE [Milutinovic and Trendafiloski 2003], SYNER-G [Hancilar and Taucer 2013], EMCA [Wieland et al. 2015] and CSA [Lang et al. 2018]). Table 1 shows different international methodologies for vulnerability ranking. Note that the most significant differences between the number of building typologies $\left(N_{t}\right)$ and the number of classes $\left(\mathrm{N}_{\mathrm{vc}}\right)$ are at a global scale. The proportion of number of classes compared to number of typologies for each methodology are higher in the studies carried out in the U.S. (HAZUS and ATC-13), which are also the oldest. In more recent and local methodologies (EMCA, CSA), these percentages are lower. The current trend is to minimize the number of vulnerability classes assigned in order to ensure more efficient studies.

There are other ways to approach classifying typologies. For example, the GEM Buiding Taxonomy (Brzev et al. 2012) categorizes buildings according to attributes that affect seismic behavior. The most recent version of the GEM describes 13 attributes in detail. Because of this exhaustive level of detail,

Table 1. Overview of differences between the number of typologies and number of vulnerability classes in major studies.

\begin{tabular}{|c|c|c|c|c|c|}
\hline Year & Name & Region & $\begin{array}{l}N^{0} \text { building of Typologies } \\
\left(N_{t}\right)\end{array}$ & $\begin{array}{c}N^{0} \text { Vulnerability Classes } \\
\left(\mathrm{N}_{\mathrm{vc}}\right)\end{array}$ & $\mathrm{N}_{\mathrm{t}}-\mathrm{N}_{\mathrm{vC}}$ \\
\hline 1985 & ATC-13 & U.S. & 40 & 17 & 23 \\
\hline 1988 & HAZUS-MH & U.S. & 36 & 15 & 21 \\
\hline 1998 & EMS-98 & Europe & 15 & 4 & 11 \\
\hline 2000 & aWHE & Global & 45 & 14 & 31 \\
\hline 2002 & RISK-UE & Europe & 65 & 23 & 42 \\
\hline 2008 & aAPAGER & Global & 81 & 9 & 72 \\
\hline 2013 & EMCA & Central Asia & 16 & 6 & 10 \\
\hline 2017 & CSA & Central and South Asia & 29 & 9 & 20 \\
\hline
\end{tabular}

${ }^{4} 45$ WHE subtypes over 14 load-bearing typologies ${ }^{* *} 81$ typologies over nine classes of materials 
the study is more a description of each building (exposition) than a classification of buildings. It is difficult to understand the acronym assigned to each building in the end. More straightforward classifications of building attributes can be identified quickly before classify vulnerability. Torres et al. (2019) and Meyers, Gaspar-Escribano, and Martínez-Cuevas (2019) created robust exposure and vulnerability databases with different areas of application. The first one used satellite images in two cities in Spain and Central America and the second one implemented a collaborative mapping approach in the urban center of Valdivia Chile. In Grigarotos et al., 2018 the advent of low-cost technologies enabled crowdsourcing the required in situ data, they present exposure data for seismic vulnerability assessment in Nablus (Palestine), based on Volunteered Geographic Information, and a new collection form to gather building data.

Learning from earthquakes is a continuing activity. Every major event provides additional data that can be used to improve building codes, insurance ratings, and disaster management practices. The Cambridge Earthquake Database CEQID (Spence et al. 2011) is a critical component of risk datasets. Currently, the CEQID contains data on 76 significant earthquakes that took place between 1906 and 2016. The database details damage in more than 2,000 locations that affected over 200 distinct structural typologies (Spence et al. 2018).

Vulnerability studies classify building typologies taking into account the structure and behavior modifiers mainly. This study also includes urban modifiers for the definition of typologies and the soil conditions at the building site to assess building habitability. The approach presented in this paper identify building typologies based on a complete definition of the type of structure, the urban configuration and the soil condition of the building location. This study identify which building typologies are correlated with damage and, consequently, assessing building habitability after an earthquake.

\section{Methodology Developed to Classify Building Habitability}

To classify building habitability, a statistical methodology consisting of three phases was developed (Fig. 2):

(1) The initial phase entailed creating a database and selecting the sample from the established study area as well as gathering all the data about the buildings: type of structure, urban modifiers, class of soil on which each building was built and damage experienced. The buildings were divided by type of structure: masonry or reinforced concrete. The urban

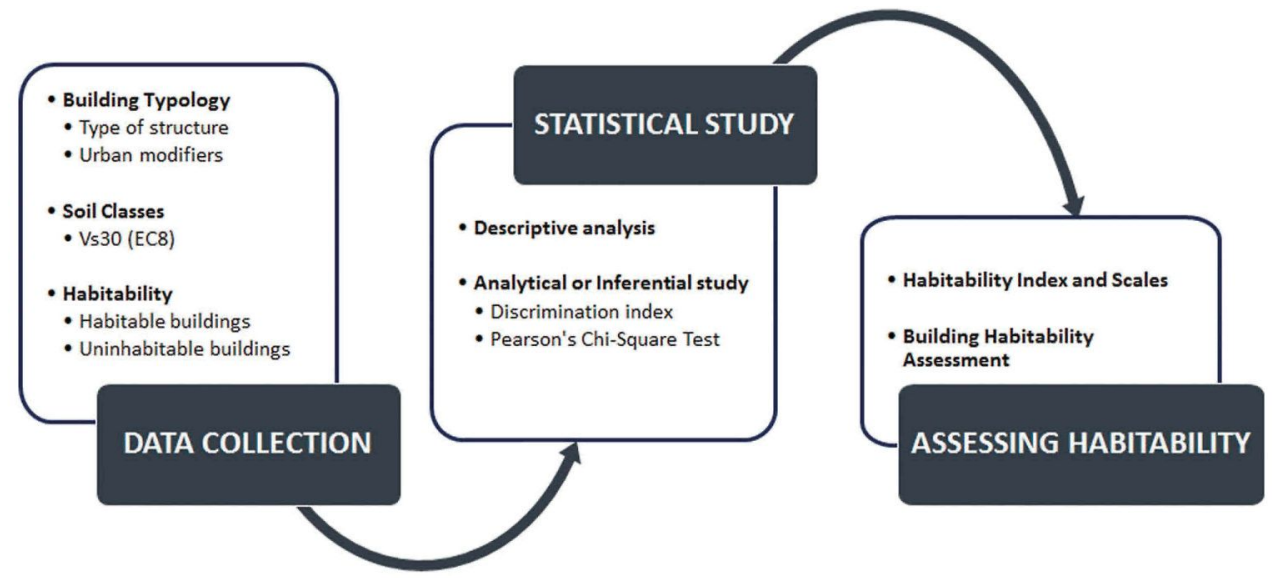

Figure 2. Outline of the process followed during the research study, with three distinct phases in the methodology used to classify buildings. 
modifiers analyzed were taken from Martínez-Cuevas et al. (2017). Moreover, soil classes were classified according to the Vs30 value distribution proposed in Eurocode EC8 (1998). Also, the buildings were assigned habitability ratings of either habitable (no damage or no structural damage) or uninhabitable (structural damage). The class "no damage" refers to buildings that only suffered minor damage or no damage; and the class "no structural damage" means that the building suffered slight damage, the falling of objects can immediately be avoided and the original load-bearing capacity does not appear to have been significantly compromised, there is no damage to the structural elements.

(2) In the second phase, the variables were studied using descriptive and inferential statistics. The sample was classified by building typology (structure and modifiers/parameters) and soil class. Urban modifiers/design parameters were identified in each of the samples, and inferential statistics were used to determine whether these modifiers/parameters correlation were correlated with damage. We were able to determine which modifiers/parameters were correlated with no damage and no structural damage (habitability) and which were correlated with structural damage (non-habitability).

(3) And lastly, we also identified building typologies that were correlated with habitability and non-habitability. In this phase, modifiers/parameters that were correlated with structural or no structural damage were grouped. These modifiers/parameters were then associated with the corresponding type of structure to obtain a ranking of typologies by degree of habitability. Subsequently, these typologies were subdivided according to the kind of soil on which the building was built.

To guarantee the validity of the study, the sample selected had to represent a minimum number of building attributes that affect seismic behavior (the type of structure and urban modifiers). Moreover, to classify buildings as habitable or uninhabitable, it was necessary to ensure that the sample included the full range of damage and that the different types of soil were identified according to the Vs 30 value distribution.

Descriptive statistics were used to collect, classify, represent, and summarize data, while analytical and inferential statistics were used to find correlations or associations between the characteristics observed, in other words, to extract scientific consequences from the study data. Our study purports to demonstrate the correlations between damage and the following variables or attributes: type of structure, urban modifiers, and soil class.

Therefore, before applying statistical procedures, in addition to assessing building habitability, it was also necessary to build a database of variables, shapes, descriptions of shapes, types of variables, and their levels.

After completing the inferential study, urban modifiers that were correlated with damage were grouped to form ratings of habitable and uninhabitable buildings according to the type of soil on which the buildings were built and the type of structure.

\section{Analytical or Inferential Study Methodology}

\subsection{Discrimination Index for Urban Modifiers/Parameters and Building Habitability}

After selecting our sample and identifying the type of structure and modifiers/parameters for the building, the first step was to determine whether these were correlated with no damage or no structural damage (habitable buildings) or with structural damage (uninhabitable buildings).

To establish this correlation, we defined a discrimination index, $i$ (Eq. 1), as well as carrying out an association analysis with contingency tables in order to check the relationship between urban modifiers and the observed damage. This type of discrimination index is used in analyzing items for objective tests. The discrimination index (i) indicates the extent to which an item is discriminate, organizing candidates according to the scores obtained in the test being analyzed. In the present study, 


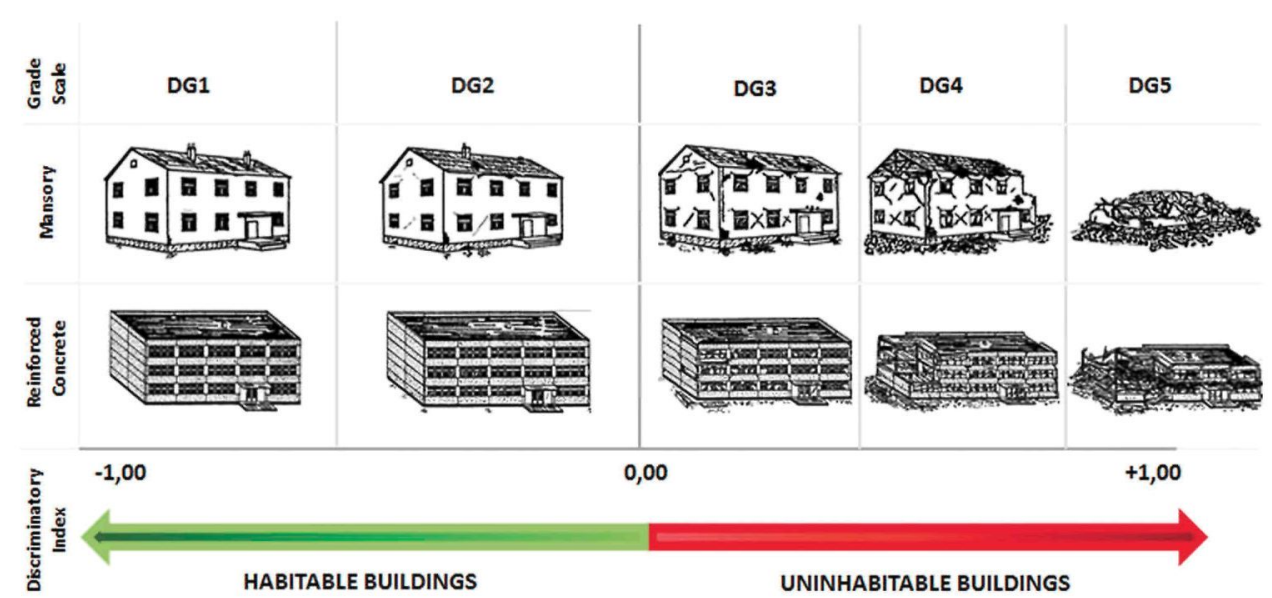

Figure 3. Discrimination index values versus degrees of building damage according to EMS 98.

this data is part of every level or every urban modifier and indicates to what extent a given level is discriminate. The study differentiates between levels that apply to buildings with structural damage (uninhabitable) and those that apply to buildings with no damage or no structural damage (habitable). This differentiation is achieved by comparing the percentage of buildings with structural damage that feature a particular level of a given urban modifier with the percentage of buildings featuring that same level that have not experienced structural damage, see equation eq. 1.

$$
i=\frac{N^{\circ} m u E}{N^{\circ} E}-\frac{N^{\circ} m u N E}{N^{\circ} N E}
$$

Where

$\mathrm{i}=$ discrimination index

$\mathrm{N}^{\circ} \mathrm{muE}=$ number of buildings with structural damage featuring a given level of an urban modifier

$\mathrm{N}^{\circ} \mathrm{muNE}=$ number of buildings with no damage or no structural damage featuring a given level of an urban modifier

$\mathrm{No} \mathrm{E}=$ number of buildings with structural damage

$\mathrm{NoNE}=$ number of buildings with no damage or no structural damage

This index makes it possible to offer a quantitative assessment of the extent of structural and no damage or no structural damage. The greater the difference between levels that have or have not experienced structural damage, the extreme values being 0 and \pm 1 , the higher the index value. These values are represented in Fig. 3. The different Damage Grades (DG) are associated with the discrimination index as follows: DG 1 and DG 2 are associated with no damage and no structural damage, being the index value between -1 and 0 ; and DG 3, DG 4, and DG 5 are associated with structural damage and index values ranging from 0 to +1 . The value 0 represents an equal percentage of buildings with and without structural damage. The maximum values in this index are +1 and -1 . The best possible value is -1 , which means that all the buildings that have not experienced structural damage feature the given urban modifier level. The same reasoning is used to indicate that if the discrimination index is +1 , every building that has suffered structural damage features the urban modifier level analyzed. Levels with negative discrimination are correlated with no damage or no structural damage, while positive values are correlated with structural damage. Highly discriminate values range from -0.5 to -1 and correspond to levels that are less closely correlated with damage, while values between +0.5 to +1 correspond to levels that are more closely correlated with structural damage. 


\section{Pearson's Chi-Square Test}

Pearson's Chi-Square Test $\left(\chi^{2}\right)$ is a statistical test that is used to compare hypotheses. It is used to analyze qualitative and categorical variables and compare ratios (percentages). Whenever there is a need to analyze data that are grouped into categories and presented in terms of the frequency with which each category occurs, it is advisable to consider using Chi-Square.

In the present study, nominal polytomous variables for each urban modifier level were dichotomized to analyze the association or correlation between each urban modifier level and the extent of structural damage variable. The Pearson Chi-Square Test was applied to study this association or correlation using the following steps (Sánchez-Villegas 2014).

(1) Presenting the null hypothesis as applied to our study

The null hypothesis is confirmed when the same proportion of cases that feature the dichotomized forms of the urban modifier is present in both groups: structural damage and no damage or no structural damage. In other words, the hypothesis is confirmed when the dichotomized urban modifier level (under analysis) is unrelated to structural damage. The alternative hypothesis is that the proportion of the urban modifier form (under analysis) is different when there is structural damage compared to when there is no structural damage. That is:

Null hypothesis: $\mathrm{H}_{0}$ : the dichotomized urban modifier level (under analysis) is uncorrelated or independent of structural damage.

Alternative hypothesis: $\mathrm{H}_{1}$ : the dichotomized urban modifier level (under analysis) is correlated with structural damage.

(2) Building the corresponding $2 \times 2$ Tables (using observed data), where the rows represent the dichotomized urban modifier level (under analysis) (for instance: for the geometric shape of the building plan, the urban modifier is Irregular Plan and takes the following values: 1 for Regular Plan; 2 for Other Shapes) while the columns represent the extent of damage (1. Structural, 2. No damage or No structural). (See Table 2)

(3) Calculating expected values (Model). These are calculated based on the tables in Section 2, but using only the total (or "marginal") values in the rows and columns. The total for each row was multiplied by the total for each column and divided by the total number of observations (Eq. 2).

$$
\text { Model }_{i j}=E_{i j}=\frac{\left(\text { Row } \text { Total }_{i}\right)\left(\text { Column Total }_{j}\right)}{\mathrm{n}}
$$

where

$\mathrm{n}$ is the total number of observations

Table 2. Example of corresponding table for the urban modifier Irregular Plan, level Regular with observed and model data.

\begin{tabular}{llccc} 
& & \multicolumn{3}{c}{ DAMAGE } \\
\cline { 3 - 5 } $\begin{array}{c}\text { URBAN MODIFIER } \\
\text { Irregular plan }\end{array}$ & & $\begin{array}{c}\text { No damage } \\
\text { No structural damage }\end{array}$ & Structural damage & TOTAL \\
\hline Regular & Count/Observed & 334 & 82 & 416 \\
& Expected Count/Model & 322.95 & 93.04 & 416 \\
Oof Total & $79.52 \%$ & $67.76 \%$ & $76.9 \%$ \\
Other shapes & Count/Observed & 86 & 39 & 125 \\
& Expected Count/Model & 97.04 & 27.95 & 125 \\
Total & \%of Total & $20.47 \%$ & $32.23 \%$ & $23.1 \%$ \\
& Count/Observed & 420 & 121 & 541 \\
& Expected Count/Model & 420 & 121 & 541 \\
& \% of Total & $100.0 \%$ & $100.0 \%$ & $100.0 \%$ \\
\hline
\end{tabular}


Table 3. Chi-square value and $p$-value for the levels of the urban modifier Irregular Plan.

\begin{tabular}{llcc}
\hline URBAN MODIFIERS & \multicolumn{1}{c}{ LEVELS } & CHI-SQUARE $\left(X^{2}\right)$ & P-VALUE \\
\hline IRREGULAR PLAN & 1.1 REGULAR & 14.377 & 0.000 \\
& 1.2 IRREGULAR. External re-entrant corner & 5.90 & 0.015 \\
& 13 IRREGULAR. Internal re-entrant corner. & 5.787 & 0.016 \\
\hline
\end{tabular}

Table 2 shows an example of the corresponding table for an urban modifier: Irregular Plan. The rows represent the dichotomized urban modifier level and the columns represent the extent of damage. The expected count was calculated with the equation 2.

(4) The comparison statistic applied is defined as follows (Eq. 3):

$$
X^{2}=\sum\left(\frac{\left(\text { Observed }_{i j}-\text { Model }_{i j}\right)^{2}}{\text { Model }_{i j}}\right)
$$

where

i represents the rows in the table

$\mathrm{j}$ represents the columns in the table

observed data are the frequencies in the table

Where $\Sigma$ means adding the sum of all levels or cells. Therefore, the sum of the quotients between the difference squared between each observed value and the expected value, divided in turn by the expected value is denominated Chi-Square. The value of $X^{2}$ corresponds to a probability, $p$-value, that is defined as: $p$-value $=\mathrm{p}\left(\mathrm{x}>\mathrm{X}^{2} \mid \mathrm{H}_{0}\right.$ is true $)$. In summary, for a $95 \%$ confidence level:

(a) If $\mathrm{p} \geq 0.05 . \mathrm{H}_{0}$ is accepted, there is no evidence to support refuting the null hypothesis

(b) If $p<.05 . \mathrm{H}_{0}$ is refuted.

This applies when both variables in the nominal scale are qualitative and the only requirement that must be met is that none of the expected values in Tables $2 \times 2$ should be less than 5 . A maximum of $20 \%$ of frequencies below five is tolerable.

Table 3 shows an example with the Chi-square value and the $p$-value for the urban modifier Irregular Plan. In this case, all the levels are correlated with damage, as the $p$-value is less than 0.05 . High values of Chi-square result in low values of $p$-value which indicates that there is a high correlation between the level of the urban modifier and damage.

\section{Application in the 2011 Earthquake in Lorca}

\subsection{Earthquake Characteristics}

On the afternoon of May 11, 2011, two earthquakes occurred near the center of the city of Lorca. The first one, at 17:05 hours (local time), attained a magnitude of 4.5 degrees and was felt throughout the region of Murcia and in some localities in the surrounding provinces. In the city center, there were reports of some non-structural elements falling. The second earthquake was recorded at 18:47 hours. This event attained a magnitude of 5.1 degrees and was felt in places as far away as Madrid. This second earthquake left nine mortal victims and injured more than 300 people. It also provoked the evacuation of more than 10,000 inhabitants (4,000 of which were rehoused in a camp set up by the government).

The source of both of these earthquakes was located on the Alhama de Murcia Fault. The actual rupture planes were located directly beneath the city of Lorca at an epicentral and Joyne-Boore distances of 4.6 and $0 \mathrm{~km}$, respectively (Fig. 4a). The main shock focal depth was $4 \mathrm{~km}$, which partly explains the high accelerations recorded at the station in Lorca - the seismic station closest to the 


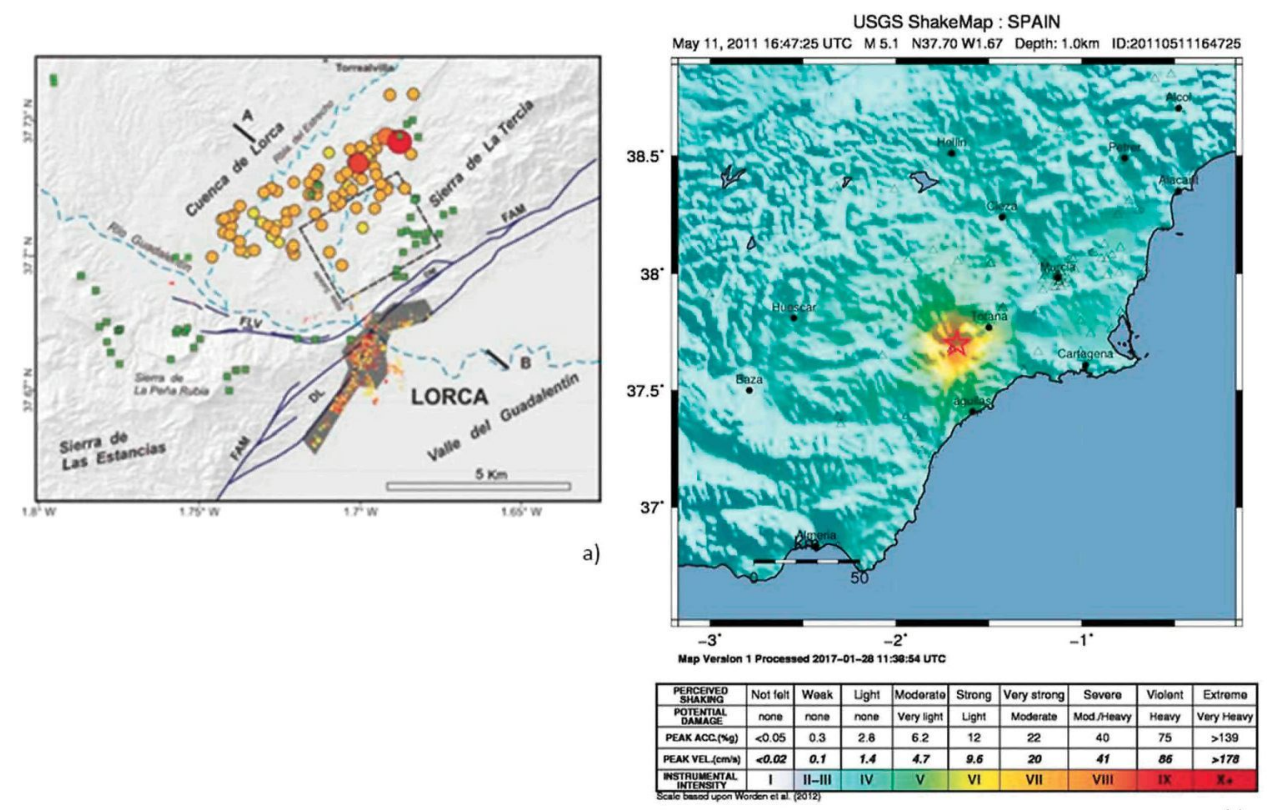

b)

Figure 4. a) 2011 Lorca main shock rupture plane (black dashed box) and location of Lorca's city center (dark gray) (Martínez-Díaz 2011). The epicenters of the seismic series are represented in red and orange. b) Shakemap of instrumental intensities for the mainshock.

Table 4. PGA and PGV values recorded for the three components and both events.

\begin{tabular}{|c|c|c|c|c|c|c|c|}
\hline $11 / 05 / 201116: 47: 25$ & $\mathrm{Mw}=5.1 \mathrm{I}=\mathrm{VII}$ & & & & & & \\
\hline STATION & Dist. Epic. (Km) & $P G A\left(\mathrm{~cm} / \mathrm{s}^{2}\right) \mathrm{E}-\mathrm{W}$ & $\mathrm{PGV}(\mathrm{cm} / \mathrm{s})$ & $P G A\left(\mathrm{~cm} / \mathrm{s}^{2}\right) \mathrm{N}-\mathrm{S}$ & PGV $(\mathrm{cm} / \mathrm{s})$ & $P G A\left(\mathrm{~cm} / \mathrm{s}^{2}\right) \mathrm{V}$ & PGV(cm/s) \\
\hline LORCA & 4.6 & 150.8 & 14.2 & 360.4 & 35.6 & 115.3 & 8.0 \\
\hline \multicolumn{8}{|c|}{$11 / 05 / 201115: 05: 13 \mathrm{Mw}=4.5 \mathrm{I}=\mathrm{Vl}$} \\
\hline STATION & Dist.Epic.(km) & $\mathrm{PGA}\left(\mathrm{cm} / \mathrm{s}^{2}\right)$ & PGV $(\mathrm{cm} / \mathrm{s})$ & $\operatorname{PGA}\left(\mathrm{cm} / \mathrm{s}^{2}\right)$ & PGV $(\mathrm{cm} / \mathrm{s})$ & $\mathrm{PGA}\left(\mathrm{cm} / \mathrm{s}^{2}\right)$ & PGV(cm/s) \\
\hline LORCA & 4.8 & 128.2 & 4.1 & 270.7 & 12.9 & 75.2 & 2.3 \\
\hline
\end{tabular}

epicenter of both events (Fig. 4b). The PGA values recorded in single horizontal components at this station were 151 and $360 \mathrm{~cm} / \mathrm{s} 2$, which are the highest ever recorded in Spain up to date. Table 4 shows the PGA and PGV values recordered.

Finally, it should be noted that, in both earthquakes, the response spectra of Spanish Building Code NCSE-02 were exceeded for both earthquakes for all soil conditions contemplated under the code. This also helps explain the vast extent of damage caused by the earthquake, given its moderate magnitude of Mw 5.1

\subsection{Damage and Habitability Assessment}

After the Lorca earthquake, buildings were ranked according to the habitability criteria established by various international guidelines, most of which are based on the documentation generated by the ATC - Applied Technology Council, 1985. Four levels of security were defined based on these criteria: White and Green (Habitable), Yellow (Restricted Use), Red (Non-Habitable), and Black (Collapse). Table 5 shows a description of damage applicable to each level of building habitability. 
Table 5. Description of damage experienced in the Lorca earthquake according to building habitability.

\begin{tabular}{|c|c|c|}
\hline $\begin{array}{l}\text { SAFETY LEVELS } \\
\text { HABITABILITY }\end{array}$ & DAMAGE & DESCRIPTION \\
\hline WHITE & DG 1 (very slight) & Buildings only suffered minor damage or no damage. \\
\hline HABITABLE & No damage & \\
\hline GREEN & DG 2 (slight) & Does not appear to be in danger. The original load-bearing capacity does not appear \\
\hline HABITABLE & No structural damage & to have been significantly compromised. The building may be used. \\
\hline YELLOW & DG 3 (moderate) & Load-bearing capacity has been significantly compromised and/or architectural \\
\hline UNINHABITABLE & Structural damage & $\begin{array}{l}\text { features significantly damaged. Occupation contingent on removal and/or repair of } \\
\text { features in danger of collapsing and/or repair of structural damage. Owners may re- } \\
\text { enter only in case of emergency and at their own risk. Continuous use of the } \\
\text { building and entry to the public are prohibited. }\end{array}$ \\
\hline RED & DG 4 (severe) & High risk, the property has suffered structural damage, and its load-bearing capacity \\
\hline UNINHABITABLE & Structural damage & $\begin{array}{l}\text { has been compromised. It may be necessary to brace the building. Possible danger } \\
\text { of collapse due to earthquake aftershocks. Entrance prohibited. }\end{array}$ \\
\hline $\begin{array}{l}\text { BLACK } \\
\text { UNINHABITABLE }\end{array}$ & $\begin{array}{l}\text { DG } 5 \text { (extreme/ } \\
\text { collapse) } \\
\text { Structural damage }\end{array}$ & $\begin{array}{l}\text { Property that has experienced widespread structural damage and is in imminent } \\
\text { danger of caving in or collapsing. The building must be evacuated entirely, } \\
\text { neighboring streets and buildings must be protected, and plans must be made to } \\
\text { demolish the damaged building. }\end{array}$ \\
\hline
\end{tabular}
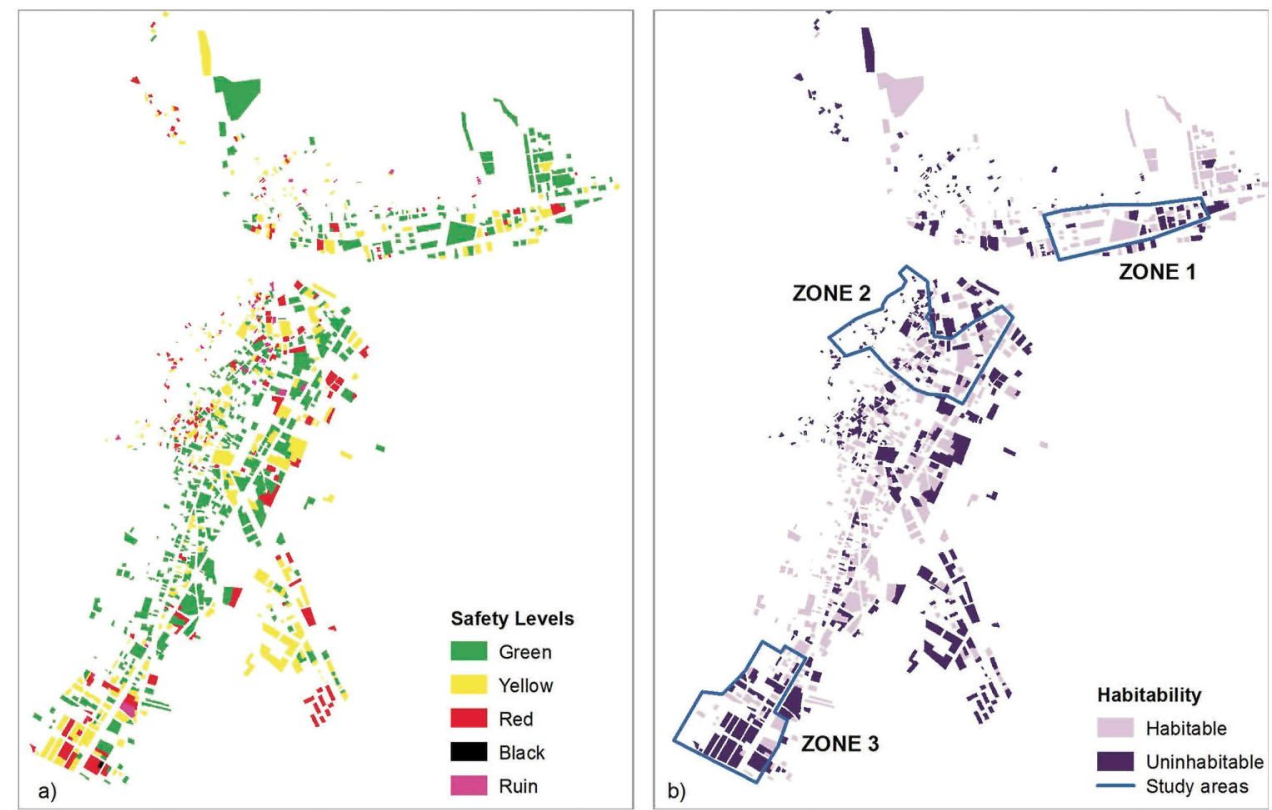

Figure 5. a) Safety levels and b) Habitability in Lorca after the earthquake.

The spatial distribution of the safety levels (Fig. 5a) and habitability in the city of Lorca (Fig. 5b), shows that the most significant number of uninhabitable buildings were in the south and the city center (Historic Quarter). However, most of the buildings in the south were rated Yellow - which, in some cases, means that habitability may vary after a quick technical intervention -, while the buildings in the center were predominantly rated Red (in danger of collapsing due to aftershocks).

\subsection{Selection of Samples for the Study}

The study areas were chosen at random, though bearing in mind that the sample had to include the full range of damage ratings. 
The most common types of structures in the city of Lorca, and in general in Spain, correspond to reinforced concrete frame-filled brick buildings (in this study reinforced concrete buildings) and unreinforced masonry buildings (in this study masonry buildings). Steel structures are also present to a lesser extent, especially in buildings with an industrial use. The incidence of retrofitted structures for residential use is rare due to the relatively low seismic activity. Thus, no strengthened buildings are considered for the study area. In case of applying this methodology in areas where this type of buildings exists, they must be analyzed separately; and the relationship between the urban modifiers and the damage should be studied.

The sample included 816 residentials buildings located in three different areas in the city of Lorca (see Fig. 5b). Zone 1 is located north of the Guadalentín River, covers the neighborhood of Barrio de San Diego and includes 91 buildings. Zone 2, south of the Guadalentín River, covers the part of the neighborhood of Barrio de Santiago (northeastern half) and part of the Barrios Altos neighborhood (northwestern half), and includes a total of 375 buildings. Zone 3, located south of the city of Lorca, covers the neighborhoods of Barrio de La Viña and Barrio de Alfonso X and includes a total of 350 buildings.

The distribution of the structural typologies observed in the sample is shown in Fig. 6. The predominant buildings types are reinforced concrete and unreinforced masonry buildings. As can be seen, the majority of the buildings have reinforced concrete structures in the three zones, with a period of construction between 1940 and the present. In Barrios Santiago and Barrios Altos (Fig. 6b.1), we found over 100 years old houses made of masonry, the oldest ones, with date of construction prior to 1700 .

The damage distribution for all the study areas gives similar percentages of moderate damage (yellow), around $10 \%$. However, there is a higher proportion of buildings with no damage or very slightly damaged (white) and slight damage (green) in Barrio San Diego (46\% white - 35\% green, Fig. 6a.2) and Barrios de la La Viña - Barrio Alfonso X (70\% white - 7\% green, Fig. 6c.2), where most of the buildings are reinforced concrete. Moderate damage (yellow) and severe damage (red) appears higher in Barrio Santiago - Barrio Altos (Fig. 6b.2) where most of the buildings are masonry.

Exhaustive fieldwork was carried out to gather all the data required to apply the proposed methodology on all variables: damage, type of structure, urban modifiers and type of soil. This last
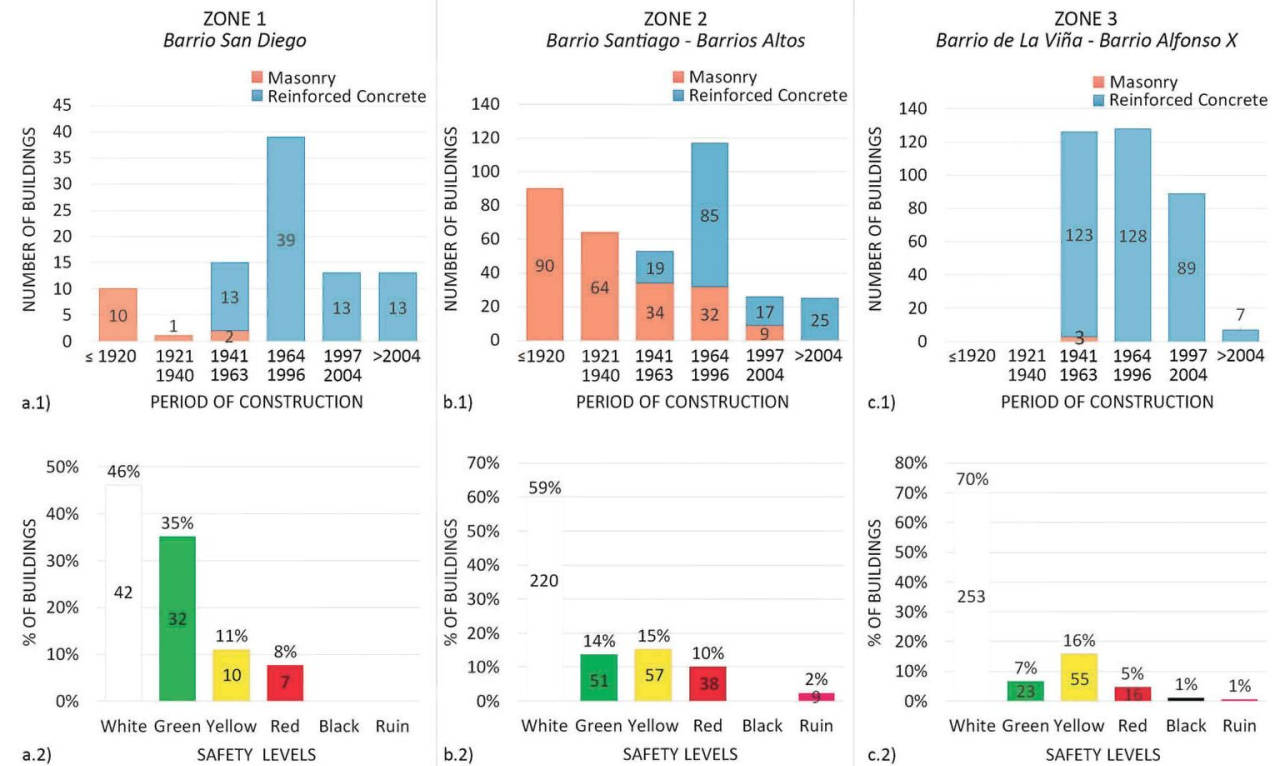

Figure 6. Distribution of the structural typologies observed in the building grouped by the period of contruction and the safety levels in the three zones of study. 
variable was based on the microzone map created by Navarro et al. (2014), based on the distribution of Vs30 values proposed in Eurocode EC8.

\section{Statistical Study to Identify Urban Modifiers Correlated with Damage}

\subsection{Database Structure}

A database was created with information on the variables to be analyzed; in essence, data about the variable, description, levels and type of variable. Table 6 shows the database structure with four columns corresponding to the fields mentioned above. The only dependent variable was damage. All other variables - modifying factors/urban design parameters, structure, and soil - behaved as independent variables. The description provides details about each variable. The levels refer to the various classes defined for each variable. Moreover, the type of variable is either nominal dichotomous or nominal polytomous, depending on the statistical analysis required. Nominal dichotomous means that only two levels are defined for the variable, while nominal polytomous indicates that the variable has more than two levels.

where MFR = Multi-Family Residential and SFR = Single-Family Residential

Nominal polytomous urban modifiers levels were dichotomized. In other words, dummy variables were created (1. level under study, 2. remaining levels). This made it possible to analyze correlations or associations between each of the levels of the variables in the study and structural damage. This was done using Pearson's Chi-Square Test.

The statistical study distinguished between two main groups of typologies:

(a) reinforced concrete buildings

(b) masonry buildings

Moreover, for statistical analysis, the data were categorized by soil class (B or C). Soil class D was not taken into account because the sample represented less than $5 \%$ of the whole. Thus its weight within the study may be considered statistically insignificant.

\subsection{Applying the Chi-Square Test}

The Pearson Chi-Square Test was applied between levels of dichotomous urban modifying factors using the damage factor with a $95 \%$ confidence level. In the present study, values of $\chi 2$ with 1 degree of freedom and a $p$-value less than $0.05(p<.05)$ evinced a statistically significant correlation between the urban modifier level under consideration and structural damage. Otherwise, no evidence was found to support refuting $\mathrm{H} 0$ (these variables were uncorrelated).

Table 7 shows only those urban modifier levels that were correlated with damage to reinforced concrete buildings in soil class $\mathrm{B}$, where the $p$-value $<0.05$. In this case, the hammering effect, vertical position, and alignment were uncorrelated. The Table 7 shows the urban modifier with its corresponding levels, the estimated discrimination index (i), the probability associating each dichotomous urban modifier with damage (p), the Chi-Square statistic, and the $p$-value. This Table was also obtained for soil class $\mathrm{C}$ and masonry structure buildings in soil classes $\mathrm{B}$ and $\mathrm{C}$.

As may be observed in Table 7 , the discriminatory index ranges from -1 and +1 . The levels that demonstrated negative discrimination were correlated with no damage or no structural damage. The probability associated with these levels ranges from $0 \%-50 \%$, with an index value of 0 representing a $50 \%$ probability. Levels that showed positive discrimination were correlated with structural damage, and the probability associated with each of these levels was between $50 \%$ and $100 \%$. 
Table 6. Definition and operability of dependent and independent variables.

\begin{tabular}{|c|c|c|c|c|}
\hline VARIABLE & & DESCRIPTION & LEVELS & TYPE OF VARIABLE \\
\hline DAMAGE & & $\begin{array}{l}\text { Characterization of the } \\
\text { damage produced in } \\
\text { buildings after an } \\
\text { earthquake. }\end{array}$ & $\begin{array}{l}\text { 1. No damage/No } \\
\text { structural damage } \\
\text { 2. Structural damage }\end{array}$ & $\begin{array}{l}\text { DEPENDENT } \\
\text { Nominal } \\
\text { Dichotomous }\end{array}$ \\
\hline \multirow[t]{10}{*}{$\begin{array}{l}\text { URBAN } \\
\text { MODIFIERS }\end{array}$} & 1. Irregular Plan & $\begin{array}{l}\text { The building plan is of } \\
\text { irregular dimensions } \\
\text { and/or proportions }\end{array}$ & $\begin{array}{l}\text { 1.1. REGULAR. } \\
\text { 1.2 IRREGULAR External } \\
\text { re-entrant corner } \\
\text { 1.3. IRREGULAR Internal } \\
\text { re-entrant corner. }\end{array}$ & $\begin{array}{l}\text { INDEPENDENT } \\
\text { Nominal Polytomous }\end{array}$ \\
\hline & 2. Vertical Irregularity & $\begin{array}{l}\text { Setbacks on building } \\
\text { facade that affect } \\
\text { seismic vulnerability }\end{array}$ & $\begin{array}{l}\text { 2.1 REGULAR } \\
\text { 2.2 IRREGULAR Closed } \\
\text { cantilever } \\
\text { 2.3 IRREGULAR Open } \\
\text { cantilever } \\
\text { 2.4.IRREGULAR Setbacks }\end{array}$ & $\begin{array}{l}\text { INDEPENDENT } \\
\text { Nominal Polytomous }\end{array}$ \\
\hline & 3. Hammering Effect & $\begin{array}{l}\text { A hammering effect } \\
\text { occurs between the } \\
\text { floors of adjacent } \\
\text { buildings }\end{array}$ & $\begin{array}{l}\text { 3.1 NOT PRESENT } \\
\text { 3.2 PRESENT Different } \\
\text { floor heights, one side } \\
\text { 3.3 PRESENTS Different } \\
\text { floor heights, two sides }\end{array}$ & $\begin{array}{l}\text { INDEPENDENT } \\
\text { Nominal Polytomous }\end{array}$ \\
\hline & $\begin{array}{l}\text { 4. Height Difference, Right } \\
\text { Side }\end{array}$ & $\begin{array}{l}\text { Height difference, }{ }_{r} \text { right } \\
\text { side }\end{array}$ & $\begin{array}{l}\text { 4.1 Difference, right side } x \\
\leq-1 \\
\text { 4.2 Same level, right side } \\
\text { 4.3 Difference, right side } x \\
\geq+1\end{array}$ & $\begin{array}{l}\text { INDEPENDENT } \\
\text { Nominal Polytomous }\end{array}$ \\
\hline & 5. Height Difference, Left Side & $\begin{array}{l}\text { Height difference, left } \\
\text { side }\end{array}$ & $\begin{array}{l}\text { 5.1 Difference, left side } \\
x \leq-1 \\
\text { 5.2 Same level, left side } \\
\text { 5.3 Difference, left side } \\
x \geq+1\end{array}$ & $\begin{array}{l}\text { INDEPENDENT } \\
\text { Nominal Polytomous }\end{array}$ \\
\hline & 6. Soft Story & $\begin{array}{l}\text { Existence of a level or } \\
\text { floor of the building } \\
\text { that is significantly } \\
\text { less rigid than the } \\
\text { other floors of the } \\
\text { building. }\end{array}$ & $\begin{array}{l}\text { 6.1 NOT PRESENT } \\
6.2 \text { PRESENT Unenclosed } \\
\text { area } \\
6.3 \text { PRESENT Partially } \\
\text { enclosed }\end{array}$ & $\begin{array}{l}\text { INDEPENDENT } \\
\text { Nominal Polytomous }\end{array}$ \\
\hline & 7. Short Column & $\begin{array}{l}\text { The short column } \\
\text { effect occurs due to } \\
\text { an accidental } \\
\text { modification in the } \\
\text { original structural } \\
\text { configuration of the } \\
\text { columns in a } \\
\text { structural frame. }\end{array}$ & $\begin{array}{l}\text { 7.1 NOT PRESENT } \\
7.2 \text { PRESENT }\end{array}$ & $\begin{array}{l}\text { INDEPENDENT } \\
\text { Nominal } \\
\text { Dichotomous }\end{array}$ \\
\hline & 8. Urban Typology & $\begin{array}{l}\text { Multifamily versus } \\
\text { single-family } \\
\text { residential urban } \\
\text { building typology }\end{array}$ & $\begin{array}{l}\text { 8.1 MFR Urban enclosed } \\
\text { block } \\
8.2 \text { MFR Historic urban } \\
\text { block } \\
\text { 8.3 MFR Isolated open } \\
\text { block } \\
\text { 8.4 MFR Closed open } \\
\text { block } \\
\text { 8.5 SFR Row houses } \\
\text { 8.6 SFR Detached in } \\
\text { closed blocks }\end{array}$ & $\begin{array}{l}\text { INDEPENDENT } \\
\text { Nominal Polytomous }\end{array}$ \\
\hline & $\begin{array}{l}\text { 9. Aggregate Building } \\
\text { Position }\end{array}$ & $\begin{array}{l}\text { Position of the building } \\
\text { within the urban } \\
\text { block }\end{array}$ & $\begin{array}{l}9.1 \text { Isolated } \\
9.2 \text { Middle } \\
9.3 \text { Corner } \\
9.4 \text { Header }\end{array}$ & $\begin{array}{l}\text { INDEPENDENT } \\
\text { Nominal Polytomous }\end{array}$ \\
\hline & 10. Alignments & $\begin{array}{l}\text { Location of the } \\
\text { building relative to } \\
\text { its official lineup }\end{array}$ & $\begin{array}{l}\text { 10.1 Aligned } \\
\text { 10.2 Un-Aligned }\end{array}$ & $\begin{array}{l}\text { INDEPENDENT } \\
\text { Nominal } \\
\text { Dichotomous }\end{array}$ \\
\hline
\end{tabular}


Table 6. (Continued).

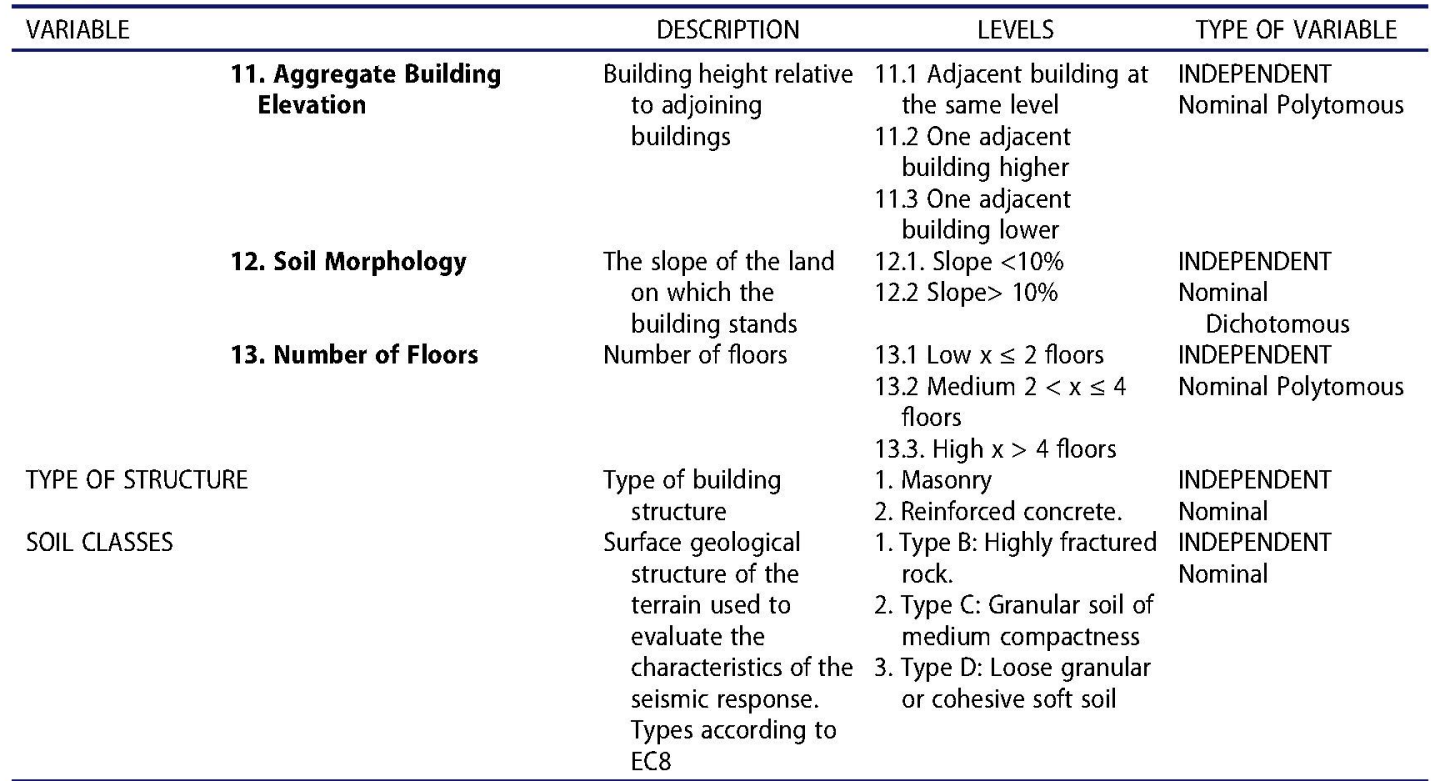

\subsection{Interpretation of Results of the Statistical Study: Correlation between Damage and Modifiers}

As mentioned, the study analyzed soil class B and C, and both masonry and reinforced concrete structural systems. One initial observation was that there is that soil class $\mathrm{B}$ showed a stronger correlation with damage than type $\mathrm{C}$ soil. Moreover, reinforced concrete buildings experienced much more damage than masonry buildings.

In soil class B, concrete buildings with a soft story and vertical irregularity (setbacks) showed a higher probability of structural damage (75\%), as did buildings more than two stories high grouped in enclosed block. Some modifiers, buildings less than two stories high with a regular vertical shape, no soft story and in row houses, showed no correlation with structural damage in this kind of soil and for this type of construction. However, masonry buildings were much more strongly correlated with no structural damage than with structural damage. Buildings with a regular vertical shape that were also grouped in row houses were more likely to be habitable after the earthquake. These results are consistent with recent vulnerability studies (Nazmfar 2019) that have identified higher-density (enclosed block) urban layouts and height as more vulnerable and consequently more prone to damage.

In soil class $\mathrm{C}$, reinforced concrete buildings were more strongly correlated with damage when they featured such urban modifiers as closed cantilevers and a soft story. On the other hand, buildings up to two stories in height, with open cantilevers and no soft story were more strongly correlated with no damage. In this same type of soil, masonry buildings showed no correlation with either structural damage or no damage.

Figure 7 shows the discrimination index and percentage of damage, organized by typology, for some modifiers in soil class B. As mentioned above, discrimination index values from 0 to 1 indicate structural damage (uninhabitable buildings) while values between 0 to -1 indicate that there was no structural damage (habitable buildings). One of the results obtained for both masonry and reinforced concrete is that regular urban modifiers, a regular geometric shape both on the vertical axis and in the plan, are more closely correlated with no damage or no structural damage, while irregular modifiers are correlated with structural damage (Fig. $7 \mathrm{~b}$ ). These results corroborate the findings of 
Table 7. Urban modifier levels correlated with damage to reinforced concrete buildings in soil class B.

\begin{tabular}{|c|c|c|c|c|}
\hline Urban Modifiers & $\mathrm{i}$ & $\mathrm{p}$ & Chi-Square & p-value \\
\hline $\begin{array}{l}\text { 1. Irregular Plan } \\
\text { 1.1 REGULAR } \\
\text { 1.2 IRREGULAR. External re-entrant corner } \\
\text { 13 IRREGULAR. Internal re-entrant corner. }\end{array}$ & $\begin{array}{r}-0.163318 \\
0.080452 \\
0.070521\end{array}$ & $\begin{array}{l}0.418341 \\
0.540226 \\
0.535260\end{array}$ & $\begin{array}{l}14.377 \\
5.90 \\
5.787\end{array}$ & $\begin{array}{l}0.000 \\
0.015 \\
0.016\end{array}$ \\
\hline $\begin{array}{l}\text { 2. Vertical Irregularity } \\
\text { 2.1 REGULAR. } \\
\text { 2.4 IRREGULAR. Setbacks }\end{array}$ & $\begin{array}{r}-0.415425 \\
0.480889\end{array}$ & $\begin{array}{l}0.292287 \\
0.740445\end{array}$ & $\begin{array}{l}44.617 \\
70.907\end{array}$ & $\begin{array}{l}0.000 \\
0.000\end{array}$ \\
\hline $\begin{array}{l}\text { 5. Height Difference, Left Side } \\
\text { 5.1 Difference, left side } x \leq-1 \\
\text { 5.2 Same level, left side }\end{array}$ & $\begin{array}{r}0.106419 \\
-0.144868\end{array}$ & $\begin{array}{l}0.553209 \\
0.427566\end{array}$ & $\begin{array}{r}8.545 \\
10.395\end{array}$ & $\begin{array}{l}0.003 \\
0.001\end{array}$ \\
\hline $\begin{array}{l}\text { 6. Soft Story } \\
\text { 6.1 NOT PRESENT } \\
6.3 \text { PRESENT. Partially Enclosed }\end{array}$ & $\begin{array}{r}-0.488406 \\
0.473509\end{array}$ & $\begin{array}{l}0.255797 \\
0.736755\end{array}$ & $\begin{array}{l}68.9 \\
67.938\end{array}$ & $\begin{array}{l}0.000 \\
0.000\end{array}$ \\
\hline $\begin{array}{l}\text { 7. Short Column } \\
\text { 7.1 NOT PRESENT } \\
\text { 7.2 PRESENT }\end{array}$ & $\begin{array}{l}-0.095075 \\
-0.095075\end{array}$ & $\begin{array}{l}0.452462 \\
0.547538\end{array}$ & $\begin{array}{l}22.625 \\
22.625\end{array}$ & $\begin{array}{l}0.000 \\
0.000\end{array}$ \\
\hline $\begin{array}{l}\text { 8. Urban Typology } \\
\text { 8.1 M.F.R. Urban enclosed block } \\
\text { 8.2 M.F. R. Historic urban block } \\
\text { 8.4 M.F.R. Closed open block } \\
\text { 8.5 S.F.R. Row houses } \\
\text { 8.6 S.F.R. Detached in closed blocks }\end{array}$ & $\begin{array}{r}0.434787 \\
0.083003 \\
0.127420 \\
-0.506674 \\
-0.174434\end{array}$ & $\begin{array}{l}0.717393 \\
0.541502 \\
0.563710 \\
0.246663 \\
0.412783\end{array}$ & $\begin{array}{r}88.119 \\
4.924 \\
11.307 \\
65.953 \\
12.040\end{array}$ & $\begin{array}{l}0.000 \\
0.026 \\
0.001 \\
0.000 \\
0.001\end{array}$ \\
\hline $\begin{array}{l}\text { 9. Aggregate Building Position } \\
\text { 9.1 Isolated } \\
\text { 9.2 Middle } \\
\text { 9.4 Header }\end{array}$ & $\begin{array}{r}0.043278 \\
-0.263177 \\
0.109380\end{array}$ & $\begin{array}{l}0.521639 \\
0.368411 \\
0.554690\end{array}$ & $\begin{array}{r}4.232 \\
17.440 \\
4.286\end{array}$ & $\begin{array}{l}0.040 \\
0.000 \\
0.038\end{array}$ \\
\hline $\begin{array}{l}\text { 12. Soil Morphology } \\
\text { 12.1 Slope }<10 \% \\
12.2 \text { Slope }>10 \%\end{array}$ & $\begin{array}{l}-0.110519 \\
-0.110519\end{array}$ & $\begin{array}{l}0.444741 \\
0.555259\end{array}$ & $\begin{array}{l}4.781 \\
4.781\end{array}$ & $\begin{array}{l}0.029 \\
0.029\end{array}$ \\
\hline $\begin{array}{l}\text { 13. Number of Floors } \\
\text { 13.1 Low } x \leq 2 \text { stories } \\
\text { 13.2 Medium } 2<x \leq 4 \text { stories } \\
\text { 13.3. High } x>4 \text { stories }\end{array}$ & $\begin{array}{r}-0.698419 \\
0.449820 \\
0.248599\end{array}$ & $\begin{array}{l}0.150790 \\
0.724910 \\
0.624300\end{array}$ & $\begin{array}{r}126.686 \\
73.153 \\
26.228\end{array}$ & $\begin{array}{l}0.000 \\
0.000 \\
0.000\end{array}$ \\
\hline
\end{tabular}

where:

urban modifiers: dichotomized urban modifier levels.

i: discrimination index

p: probability correlating each dichotomized urban modifier level with damage

chi-square: Chi-Square statistical calculation.

p-value: significance of contrast.

other studies (Guevara 2010; Lagomarsino and Giovinazzi 2006) that have detected greater vulnerability in irregular buildings. In addition, in the urban typology modifier (Fig. 7a), single-family dwellings were more strongly correlated with no damage and no structural damage. Meanwhile, in the number of floors modifier (Fig. 7c), buildings taller than two stories were correlated with structural damage.

With respect to urban typology (Fig. 7a), reinforced concrete buildings with higher density housing, multi-family residential buildings (enclosed blocks, historic urban block and open blocks), were correlated with structural damage. According to Hossein Nazmfar (2019), the most vulnerable buildings are those with more than 200 homes. This finding was corroborated in our study in the dense enclosed block modifier, which represents $72 \%$, the highest percentage of structural damage. For the high-density urban typology modifier, masonry buildings did not show a correlation with damage because this type of housing is composed predominantly of reinforced concrete structural systems. 


\section{URBAN TYPOLOGY}

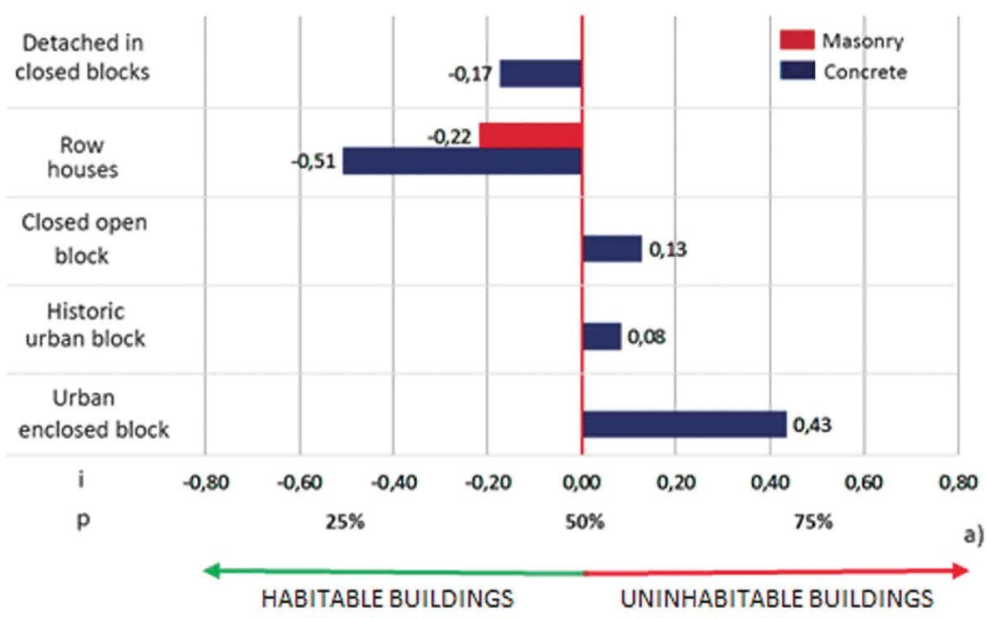

VERTICAL IRREGULARITY

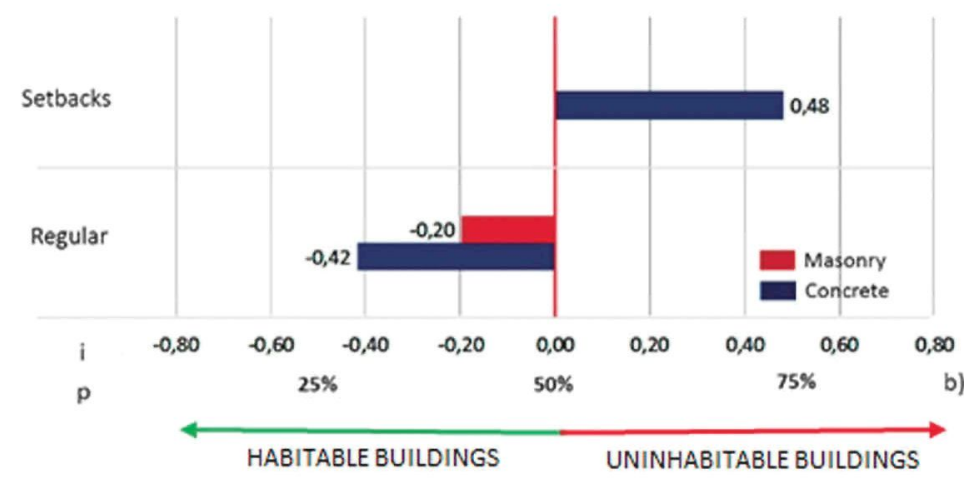

NUMBER OF FLOORS

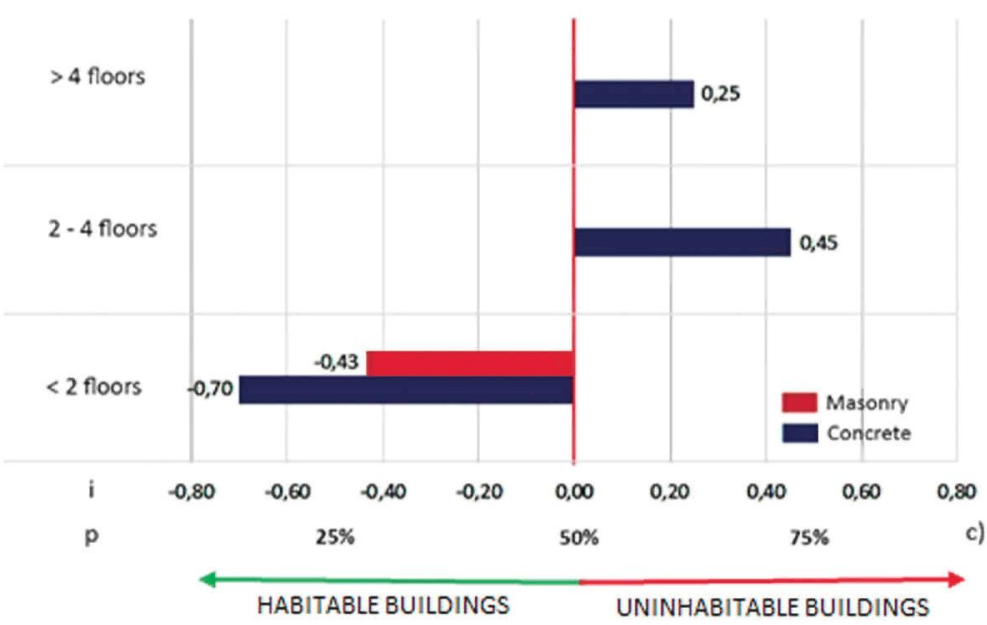

Figure 7. Damage index and percentage of damage for urban modifiers: a) urban typology, b) vertical irregularity and c) height for masonry and reinforced concrete structural typologies in soil class $B$. 


\section{Assessing Habitability of Building Typologies}

\subsection{Habitability Index and Scales}

The results obtained were used to create a habitability scale for soil classes B and C to estimate the probability of damage associated with each urban modifier level. The habitability index was divided into six sections, three representing no damage or no structural damage, and three representing structural damage. Each of these sections is associated with a percentage of damage. As mentioned above, the percentage of structural damage was higher than $50 \%$, and the scale presents three percentage ranges: $50 \%-66 \%, 66 \%-82 \%$ and $82 \%-100 \%$, with the latter representing the strongest correlation with structural damage.

Figure 8 shows the different levels of modifiers that were associated with damage and their correlation with habitability after an earthquake in soil classes B and C. It is worth noting that, for concrete structures in soil class B, many levels (14 in all) were correlated with non-habitability. Concrete structures in soil class $\mathrm{C}$ were also more closely correlated with damage than masonry structures; although, in this case, both building habitability and non-habitability for concrete buildings were correlated with six levels. The colors used represent the following: red indicates that there is a correlation between the level and non-habitability and green represents a correlation with habitability. Increasingly more intense or darker shades of each color are used to represent the strength of these correlations. Thick lines are used to represent the reinforced concrete construction typology, while thin lines represent the masonry construction typology.

\begin{tabular}{|c|c|c|c|c|}
\hline \multirow{3}{*}{$\begin{array}{l}\text { SOIL CLASS B } \\
\text { URBAN MODIFIER }\end{array}$} & \multicolumn{4}{|c|}{ HABITABILITY SCALE } \\
\hline & \multicolumn{2}{|c|}{ HABITABLE } & \multicolumn{2}{|c|}{ UNINHABITABLE } \\
\hline & MANSORY & CONCRETE & MANSORY & CONCRETE \\
\hline \multicolumn{5}{|l|}{ PLAN IRREGULARITY } \\
\hline \multicolumn{5}{|l|}{ 1.1 REGULAR } \\
\hline 1.2 IRREGULAR. External re-entrant corner & & & & 0 \\
\hline 1.3 IRREGULAR. Internal re-entrant corner & & & & 0 \\
\hline \multicolumn{5}{|l|}{ VERTICAL IRREGULARITY } \\
\hline 2.1 REGULAR & ○ & 0 & & \\
\hline 2.4 IRREGULAR. Setbacks & & & & 0 \\
\hline \multicolumn{5}{|l|}{ HEIGHT DIFFERENCE } \\
\hline 5.1 Difference, left side $x<=1$ & & & & 0 \\
\hline \multicolumn{5}{|l|}{ 5.2 Same level, left side } \\
\hline \multicolumn{5}{|l|}{ 4.3 Difference, right side $x>=1$} \\
\hline \multicolumn{5}{|l|}{ SOFT STORY } \\
\hline 6.1 NO PRESENT & & 0 & & \\
\hline 6.3 PRESENT. Partially closed & & & & 0 \\
\hline \multicolumn{5}{|l|}{ SHORT COLUMN } \\
\hline \multicolumn{5}{|l|}{ 7.1 NO PRESENT } \\
\hline 7.2 PRESENT & & & & 0 \\
\hline \multicolumn{5}{|l|}{ URBAN TYPOLOGY } \\
\hline 8.1 M.F.R. Urban enclosed block & & & & O \\
\hline 8.2 M.F.R. Historic urban block & & & & 0 \\
\hline 8.4 M.F.R. Closed open block & & & & 0 \\
\hline 8.5 S.F.R. Row houses & O & 0 & & \\
\hline \multicolumn{5}{|l|}{ 8.6 S.F.R. Detached in closed blocks } \\
\hline \multicolumn{5}{|l|}{ AGGREGATE BUILDING POSITION } \\
\hline 9.1 Isolated & & & & 0 \\
\hline 9.2 Middle & & O & & \\
\hline 9.4 Header & & & & 0 \\
\hline \multicolumn{5}{|l|}{ AGGREGATE BUILDING ELEVATION } \\
\hline 11.1 Adjacent building at same level & & O & & \\
\hline \multicolumn{5}{|l|}{ SOIL MORPHOLOGY } \\
\hline \multicolumn{5}{|l|}{ 12.1 Slope $<10 \%$} \\
\hline 12.2 Slope $>10 \%$ & & & 0 & 0 \\
\hline \multicolumn{5}{|l|}{ NUMBER OF FLOORS } \\
\hline 13.1 Low $\mathrm{x}<=2$ floors & O & $\mathrm{O}$ & & \\
\hline 13.2 Medium $2<x<=4$ floors & & & & O \\
\hline 13.3 High $x>4$ floors & & & & 0 \\
\hline
\end{tabular}

\begin{tabular}{|c|c|c|c|c|}
\hline \multirow{3}{*}{$\begin{array}{l}\text { SOIL CLASS C } \\
\text { URBAN MODIFIER }\end{array}$} & \multicolumn{4}{|c|}{ HABITABILITY SCALE } \\
\hline & \multicolumn{2}{|c|}{ HABITABLE } & \multicolumn{2}{|c|}{ UNINHABITABLE } \\
\hline & MANSORY & CONCRETE & MANSORY & CONCRETE \\
\hline PLAN IRREGULARITY & & & & \\
\hline 1.2 IRREGULAR. External re-entrant corner & & & & 0 \\
\hline 1.3 IRREGULAR. Internal re-entrant corner & & 0 & & \\
\hline VERTICAL IRREGULARITY & & & & \\
\hline 2.2 IRREGULAR. Close cantilever & & & & O \\
\hline 2.3 IRREGULAR. Open cantilever & & O & & \\
\hline HEIGHT DIFFERENCE & & & & \\
\hline 5.1 Difference, left side $x<=1$ & O & & & O \\
\hline 5.2 Same level, left side & & O & & \\
\hline SOFT STORY & & & & \\
\hline 6.1 NO PRESENT & & O & & \\
\hline 6.3 PRESENT. Partially closed & & & & O \\
\hline URBAN TYPOLOGY & & & & \\
\hline 8.2 M.F.R. Historic urban block & & & & O \\
\hline 8.5 S.F.R. Row houses & & 0 & & \\
\hline NUMBER OF FLOORS & & & & \\
\hline 13.1 Low $x<=2$ floors & & ○ & & \\
\hline 13.2 Medium $2<x<=4$ floors & & & & 0 \\
\hline
\end{tabular}

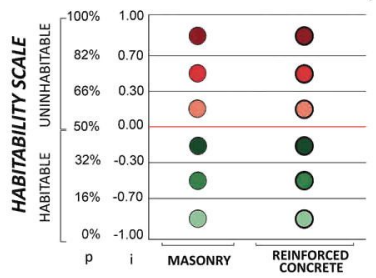

Figure 8. Habitability scales of urban modifier levels in soil classes B and C for masonry and reinforced concrete structure types. 
This type of study can be advantageous when carrying out a vulnerability analysis for a city as it makes it possible to quickly determine what buildings are in danger of becoming uninhabitable after an earthquake based on their urban modifiers. It can also be used in seismic risk plans to plan a response strategy before an earthquake, as it allows authorities to estimate the number of people who would be left homeless, determine the necessary capacity for emergency camps, and plan accordingly.

\subsection{Analysis and Results. Building Habitability Assessment}

After creating the habitability scales and identifying which urban modifier levels are most strongly correlated with structural and no structural damage, we then combined levels for each type of structure (masonry and concrete) that had a 70\% or higher probability of experiencing damage in each kind of soil. The resulting building typologies allowed us to rate the habitability of the housing stock and check the findings of other studies including the real building stock (Diana et al. 2019). These typologies were generated for both class B and class $\mathrm{C}$ soil and used to map habitability in the study areas. After comparing these results with real data from the earthquake, we were able to determine, with an accuracy rate of $76 \%$, which buildings would become uninhabitable and which would not if an earthquake of the same characteristics as the one that hit in May 2011 were to occur again in Lorca.

Figure 9 shows habitability ratings for buildings in soil class B. Note that reinforced concrete buildings with soft stories and vertical irregularity would become uninhabitable. Denser urban typologies, such as enclosed blocks, were more strongly correlated with non-habitability, while less dense urban layouts, such as rows, were correlated with habitability. Height also plays a vital role in

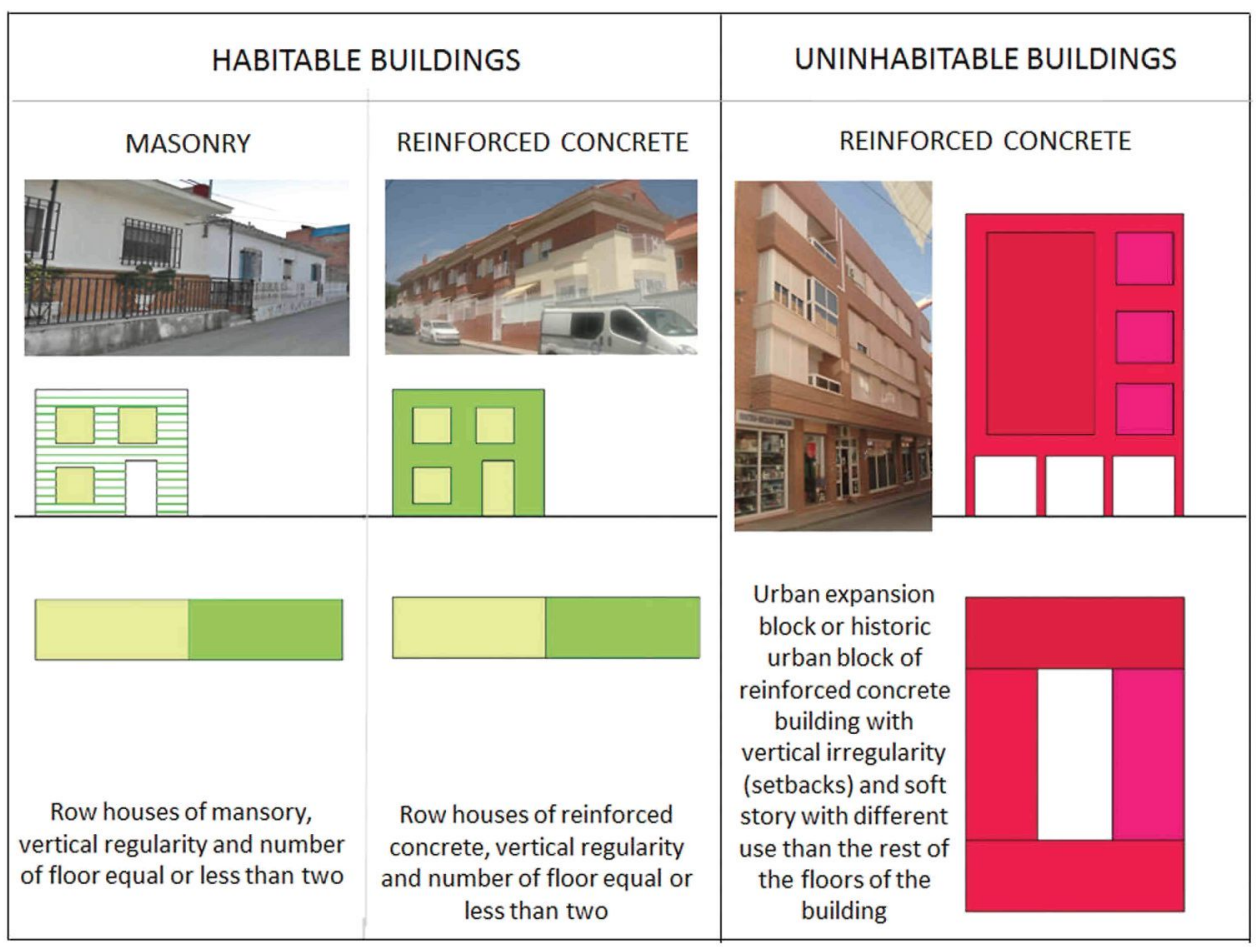

Figure 9. Building typologies likely to be habitable or uninhabitable (with a $76 \%$ accuracy in class B soil), if an earthquake with the same characteristics as the one in May 2011 were to occur again in Lorca. 


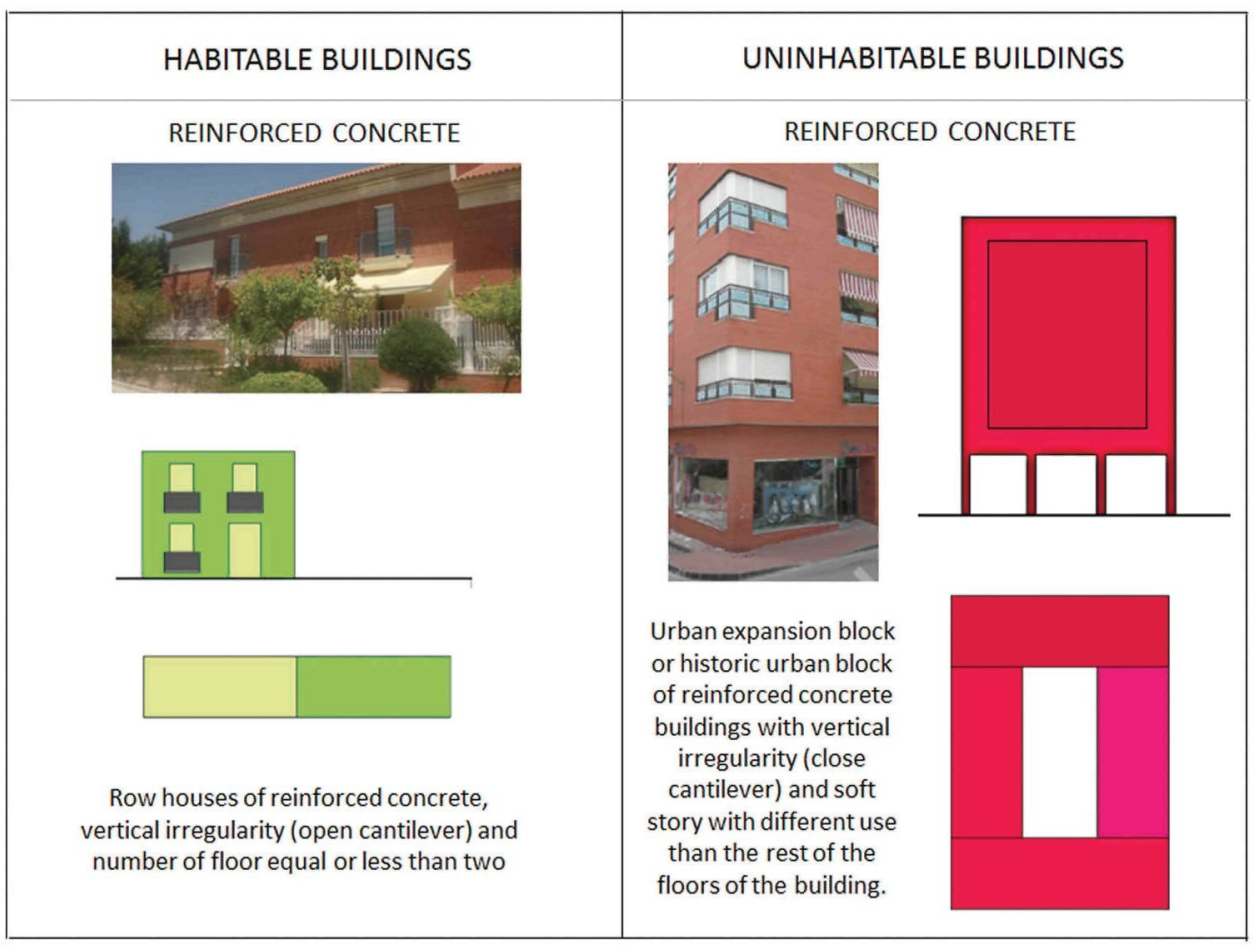

Figure 10. Building typologies likely to be habitable or uninhabitable (with a $76 \%$ accuracy rate in class $C$ soil), if an earthquake with the same characteristics as the one in May 2011 were to occur again in Lorca.

assessing building habitability. Reinforced concrete and masonry buildings no more than two stories high remained habitable.

In class C soil (Fig. 10), the only correlation found was between habitability and reinforced concrete buildings. As in soil class B, soft story, vertical irregularity, and dense urban typologies produced uninhabitable buildings. Heights of two stories or less resulted in buildings that remained habitable. The differences between the two classes of soil are evident in the different levels under the vertical irregularity modifier. Uninhabitable buildings in class B soil were correlated with setbacks in the facade while, in soil class $\mathrm{C}$, they were correlated with closed cantilevers. Conversely, habitable reinforced concrete buildings were correlated with vertical regularity in class $B$ soil and with open cantilevers in class $\mathrm{C}$ soil.

Moreover, this type of analysis makes it possible to map building habitability (Fig. 11) to provide estimates that can be used to help mitigate risk and plan first response tasks. This Fig. 11 illustrates which buildings were habitable and uninhabitable in one of the study areas (La Viña) following the earthquake (Fig. 11a) compared to the results obtained in the present study (Fig. 11b). Habitable buildings are colored green and uninhabitable buildings are red. The grey areas represent buildings whose typologies did not coincide with the actual habitability rating, and "ruin" refers to buildings that had been demolished before the earthquake. Note that, in this area, the earthquake and the study produced very similar results. The most significant coincidences occur in more recently designed urban areas (Zone 1 and Zone 3), urban expansion areas, where the road network is gridshaped, and most buildings are made of reinforced concrete. In the city center, (Zone 2), where the road network is irregular, and there is a wide variety of construction typologies, there were fewer coincidences. 


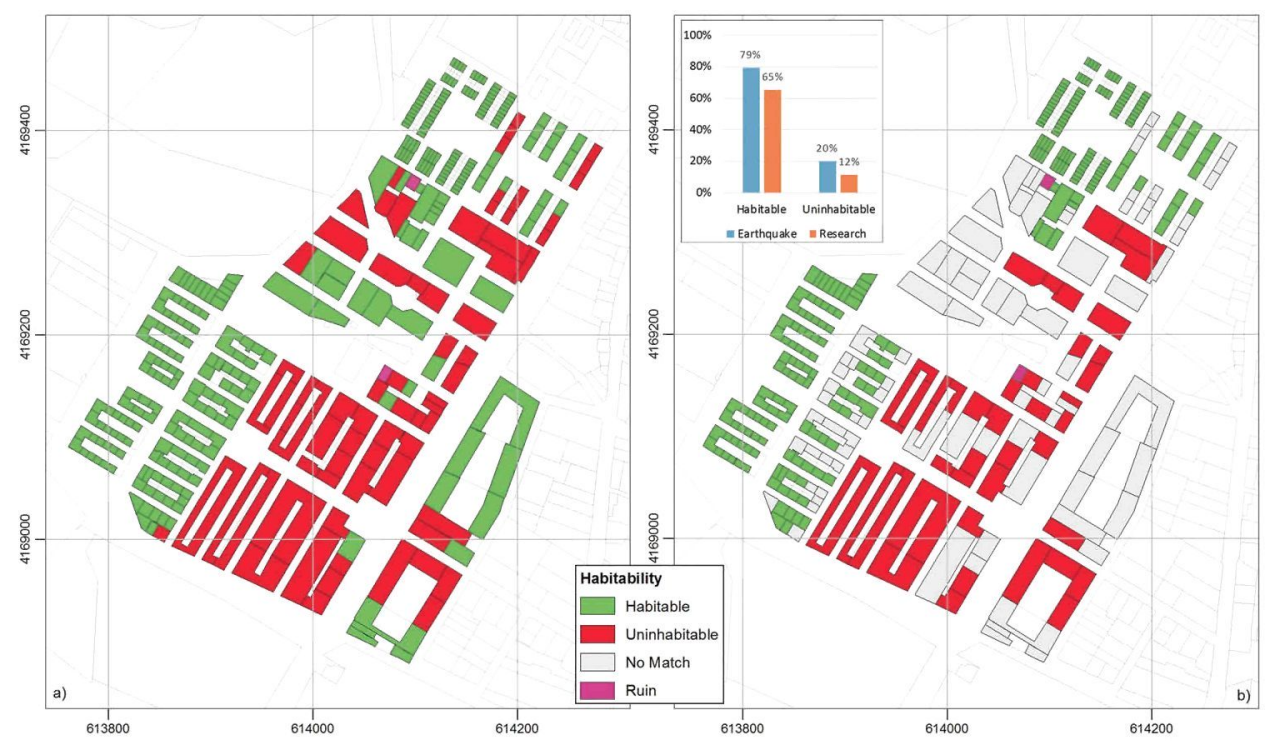

Figure 11. Map of habitable and uninhabitable buildings a) real data from the 2011 earthquake in Lorca b) habitability according to building ratings proposed in the present study.

\section{Conclusions}

The present study is another step towards assessing urban vulnerability and, more specifically, towards identifying which building typologies, (type of structure, urban configuration and soil condition of the building location) are correlated with damage and, consequently, assessing building habitability after an earthquake. Vulnerability studies classify building typologies taking into account the structure and behavior modifiers mainly. This study also includes urban modifiers for the definition of typologies and the soil conditions at the building site to assess building habitability.

The study presents a statistical analysis of urban modifiers and their correlation with damage. A discrimintaion index for each level of urban modifier is associated with a damage category, namely no damage/no structural damage or structural damage.

Buildings have been grouped according to the type of structure (masonry or reinforced concrete) and the kind of soil on which they were built as defined the corresponding Eurocode EC8 classification.

To justify the results of correlations (dependence or independence) between the various urban modifier levels and structural damage, Pearson's Chi-Square independence test was used to compare the data statistically (with a $95 \%$ confidence interval). In this type of study, it is crucial to identify the various urban modifier levels that were found to have a dependent correlation with the damage observed. Urban modifiers may be calibrated statistically in other cities using this methodology, depending on the damage observed.

In soil class B, there has been a stronger correlation between urban modifier levels and damage both in masonry and reinforced concrete buildings. Compared to masonry buildings, reinforced concrete buildings yielded a more significant number of urban modifiers that were correlated with damage. This is probably a result of the Modern Architecture Movement, which appeared during the first half of the $20^{\text {th }}$ century and has since dominated the building design and construction, urban design, and urban planning that characterize contemporary cities.

Following the statistical correlation study, urban modifiers were grouped according to their dependence or independence relative to damage and building classes were identified according to habitability. The following steps were taken to classify building typologies depending on their habitability: first, buildings are grouped according to the structural type (concrete and masonry). Then, these groups are subdivided depending on the soil condition at each building site (Vs30). Finally, the 
modifiers that are related with different damage categories (no damage/no structural damage and structural damage) are identified for each group. In addition, as the spatial analysis is carried out within a Geographical Information System (GIS), the non-habitable areas could be easily identified and mapped making it possible to project new zones where homeless families could be rehoused.

Habitability scales can be instrumental when analyzing a city's vulnerability to quickly determine which buildings are likely to become uninhabitable after an earthquake based on urban modifiers. Using these habitability assessments by building typologies, we were able to identify, with a $76 \%$ accuracy rate, which buildings would become uninhabitable and which would remain habitable if an earthquake with the same characteristics as the one in May 2011 were to occur in Lorca again. For newer urban developments, the city's expansion areas, where the urban layout is orthogonal and most buildings are made of reinforced concrete, a high percentage of the habitability assessments in the present study coincided with the real data from the earthquake. However, in areas within the city's historic center, where the layout of streets is irregular, and buildings present a wide variety of typologies, accuracy was not as high.

Modern-day vulnerability studies should include urban modifiers when classifying buildings so that vulnerability classes may be identified given building design features. The present study is a first step as it has taken these aspects into account to detected habitability typologies.

The results obtained must be conveyed to organizations in charge of city planning and managing civil and/or emergency protection so that we develop cities in a way that minimizes seismic risk and organize viable emergency plans.

This typological assessment will allow us to influence urban planning regulations and offer recommendations for each area in cities with seismic risk. We can quickly identify which buildings may experience structural damage in the event of an earthquake with the same characteristics.

This study opens a line of investigation for public authorities and experts in seismicity to work together to plan seismically stable cities.

\section{Acknowledgments}

The work presented in this paper is part of the MERISUR project: Methodology for the effective assessment of urban seismic risk, reference CGL2013-40492-R, National R+D program oriented to Societal Challenges, Ministry of Economy and Competitiveness of Spain.

\section{ORCID}

M. Carmen Morillo Balsera (iD http://orcid.org/0000-0002-0788-8394

Jorge Gaspar-Escribano (D) http://orcid.org/0000-0002-2220-7112

Alejandra Staller (1D) http://orcid.org/0000-0003-0335-0949

\section{References}

ATC (Applied Technology Council). 1985. Earthquake damage evaluation data for California. Applied Technology Council Report ATC-13, Redwood City, CA.

Benito, B., A. Rivas Medina, J. M. Gaspar-Escribano, and P. Murphy. 2012. El terremoto de Lorca 2011 en el contexto de la peligrosidad y el riesgo s1'smico en Murcia. Ft'sica de la Tierra 24: 255-87.

Brzev, S., C. Scawthorn, A. W. Charleson, and K. Jaiswal. 2012. Interim overview of GEM building taxonomy V2.0, report produced in the context of the GEM building taxonomy global component, version 1.0-December 2012, $48 \mathrm{pp}$.

CCS (Consorcio de Compensacio'n de Seguros). 2014. La Cobertura de los Riesgos Extraordinarios en España, 16 p. Ed Consorcio de Compensacio'n de Seguros.

De Risia, R., K. Godaa, and S. Tesfamariam. 2019. Multi-dimensional damage measure for seismic reliability analysis. Structural Safety 78: 1-11. doi: 10.1016/j.strusafe.2018.12.002. 
Diana, L., P. Lestuzzi, S. Podestà, and C. Luchini. 2019. Improved urban seismic vulnerability assessment using typological curves and accurate displacement demand prediction. Journal of Earthquake Engineering 1-23. doi: $10.1080 / 13632469.2019 .1597784$.

Eurocode 8. 2003. EN 1998-1: Eurocode 8: Design of structures for earthquake resistance - Part 1: General rules, seismic action and rules for buildings. Brussels, Belgium: CEN.

Grigoratos, I., R. Monteiro, P. Ceresa, A. Di Meo, M. Faravelli, and B. Borzi. 2018. Crowdsourcing exposure data for seismic vulnerability assessment in developing countries. Journal of Earthquake Engineering 1-18. doi: 10.1080/ 13632469.2018 .1537901$.

Grünthal, G. 1998. EMS-98: European macroseismic scale. Vol. 15. Luxembourg: Cahiers du Centre Européen de Géodynamique et de Séismologie.

Guevara, L. T. 2010. Seismic regulations versus modern architectural and urban configurations. Journal of Disaster Research 5 (5), October.

Hancilar, U., and F. Taucer. 2013. Guidelines for typology definition of European physical assets for earthquake risk assessment. Publications Office of the European Union. ISBN 978-92-79-28973-6.

HAZUS-99. Earthquale Loss Estimation Methodology. 1999. Earthquale loss estimation methodology, technical manual. Vol. 1. Washington: Federal Emergency Management Agency (FEMA).

IGN. 2011. Informe del sismo de Lorca de mayo de 2011, 138 p. Instituto Geogra'fico Nacional. http://www.ign.es/ign/ resources/sismologia/Lorca.pdf.

Jaiswal, K. S., and D. J. Wald. 2008. Creating a global building inventory for earthquake loss assessment and risk management. U.S. Geological Survey Open-file Report 2008-1160 106 pp.

Lagomarsino, S., and S. Giovinazzi. 2006. Macroseismic and mechanical models for the vulnerability and damage assessment of current buildings. Bulletin of Earthquake Engineering 4 (4): 415-43. doi: 10.1007/s10518-006-9024-z.

Lang, D. H. [2013]. Earthquake Damage and Loss Assessment - Predicting the Unpredictable, Dissertation for the degree doctor philosophiae. dr.philos., University of Bergen, Norway, p. 334 (ISBN: 978-82-308-2271-5). http://hdl. handle.net/1956/6753.

Lang, D. H., A. Kumar, S. Sulaymanov, and A. Meslem. 2018. Building typology classification and earthquake vulnerability scale of central and South Asian building stock. Journal of Building Engineering 15: 261-77. doi: 10.1016/j. jobe.2017.11.022.

Martínez-Cuevas, S., M. B. Benito, J. Cervera, M. C. Morillo, and M. Luna. 2017. Urban modifiers of seismic vulnerability aimed at Urban Zoning Regulations. Bulletin of Earthquake Engineering 15 (11): 4719-50. doi: 10.1007/s10518017-0162-2.

Martínez-Díaz, J. J., and J. A. Álvarez-Gómez. 2011. Seismotectonic characterization of the seismic series of Lorca and geological analysis of the earthquake source. In Geological preliminary field report of the Lorca earthquake (5.1 Mw, 11 th may 2011), Instituto Geológico y Minero de España. Internal Report. . Accessed february 14, 2012. http://www. igme.es.

Medvedev, S. W., W. Sponheuer, and V. Karnik. 1965. Seismic intensity scale version MSK 1964, 7 pp. Paris: United Nation Educational, Scientific and Cultural Organization.

Meyers, E., J. Gaspar-Escribano, and S. Martínez-Cuevas. 2019. Collaborative mapping for the assessment of seismic vulnerability and urban resilience in Valdivia (Chile). Proceedings of The Geomatics Engineering Conference, Madrid, Spain, June 26-27. doi: 10.3390/proceedings2019019001.

Milutinovic, Z. V., and G. S. Trendafiloski. 2003. RISK-UE, an advanced approach to earthquake risk scenarios with applications to different European towns. Report to WP4: Vulnerability of current buildings, September 2003, $109 \mathrm{pp}$.

Morales, J., J. V. Cantavella, F. L. Mancilla, L. Lozano, D. Stich, E. Herraiz, J. B. Martín, J. A. Lopez-Comino, and J. M. Martinez-Solares. 2014. The 2011 Lorca seismic series: Temporal evolution, faulting parameters and hypocentral relocation. Bulletin of Earthquake Engineering 12 (5): 1871-88. doi: 10.1007/s10518-013-9476-x.

Navarro, M., A. García-Jerez, F. J. Alcalá, F. Vidal, and T. Enomoto. 2014. Local site effect microzonation of Lorca town (SE Spain). Bulletin of Earthquake Engineering 12 (5): 1933-59. doi: 10.1007/s10518-013-9491-y.

Nazmfar, H. 2019. An integrated approach of the analytic network process and fuzzy model mapping of evaluation of urban vulnerability against earthquake. Geomatics, Natural Hazards and Risk 10 (1): 1512-28. doi: 10.1080/ 19475705.2019 .1588791 .

Sánchez-Villegas, A. 2014. Bioestadística amigable. M. Á. Martínez-González, \& F. J. Faulín (Eds.). Elsevier.

Spence, R., A. W. Coburn, S. Sakai, and A. Pomonis. 1991. A parameterless scale of seismic intensity for use in seismic risk analysis and vulnerability assessment. In Earthquake blast and impact: Measurement and effects of vibration, ed. The Society for Earthquake \& Civil Engineering Dynamics, 19-28. Amsterdam, Netherlands: Elsevier Applied Science.

Spence, R., S. Martinez-Cuevas, H. Baker, E. So, J. L. G. Pallero, and E. Meyers. 2018. CEQID 2018: Recent progress towards a global earthquake damage database and its use in fragility estimation. 36 th general asembly. Valletta, Malta: European Seismological commission, September 2-7. ESC2018-S39-98. 
Spence, R., E. So, S. Jenkins, A. Coburn, and S. Ruffle. 2011. A global Earthquake building damage and casualty database, Chapter 5. In Human casualties in earthquakes: Progress in modelling and mitigation, ed. R. Spence, E. So, and C. Scawthorn. Springer.

Torres, Y., J. J. Arranz, J. M. Gaspar-Escribano, A. Haghi, S. Martínez-Cuevas, B. Benito, and J. C. Ojeda. 2019. Integration of LiDAR and multispectral images for rapid exposure and earthquake vulnerability estimation. Application in Lorca, Spain. International Journal of Applied Earth Observation and Geoinformation 81: 161-75. doi: 10.1016/j.jag.2019.05.015.

Wieland, M., M. Pittore, S. Parolai, U. Begaliev, P. Yasunov, S. Tyagunov, B. Moldobekov, S. Saidiy, I. Ilyasov, and T. Abakanov. 2015. A multiscale exposure model for seismic risk assessment in Central Asia, Seismol. Research Letters 86 (1): 210-22. doi: 10.1785/0220140130. 